\title{
A COMPUTER MODEL OF GAS GENERATION AND TRANSPORT WITHIN TRU WASTE DRUMS
}

Frank G. Smith, III

\section{DO NOT MICROFILM THIS PAGE}

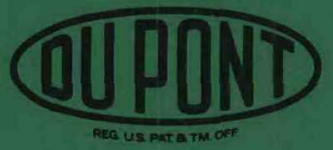

E. I. du Pont de Nemours \& Co. Savannah River Laboratory Aiken, SC 29808 
This report was prepared by E. I. du Pont de Nemours and Company (Du Pont) for the United States Department of Energy under Contract DE-AC09-76SR00001 and is an account of work performed under that Contract. Neither the United States, the United States Department of Energy nor Du Pont, nor any of their employees, makes any warranty, express or implied, or assumes any legal liability or responsibility for the accuracy, completeness, or usefulness of any information, apparatus, product, or process disclosed herein, or represents that its use will not infringe privately owned rights. Reference herein to any specific commerical product, process, or service by trade name, mark, manufacturer, or otherwise does not necessarily constitute or imply endorsement, recommendation, or favoring of same by Du Pont or by the United States Government or any agency thereof. The views and opinions of authors expressed herein do not necessarily state or reflect those of the United States Government or any agency thereof.

Printed in the United States of America

Available from

National Technical Information Service

U. S. Department of Commerce

5285 Port Royal Road

Springfiøld, Virginia 22161

Price: Printed Copy A03; Microfiche A01

\section{DO NOT MICROFILIO THIS PAGE ง




\section{DISCLAIMER}

This report was prepared as an account of work sponsored by an agency of the United States Government. Neither the United States Government nor any agency Thereof, nor any of their employees, makes any warranty, express or implied, or assumes any legal liability or responsibility for the accuracy, completeness, or usefulness of any information, apparatus, product, or process disclosed, or represents that its use would not infringe privately owned rights. Reference herein to any specific commercial product, process, or service by trade name, trademark, manufacturer, or otherwise does not necessarily constitute or imply its endorsement, recommendation, or favoring by the United States Government or any agency thereof. The views and opinions of authors expressed herein do not necessarily state or reflect those of the United States Government or any agency thereof. 


\section{DISCLAIMER}

Portions of this document may be illegible in electronic image products. Images are produced from the best available original document. 


\section{A COMPUTER MODEL OF GAS GENERATION AND TRANSPORT WITHIN TRU WASTE DRUMS}

\section{DISCLAIMER}

Frank G. Smith, III

\section{Approved by:}

G. T. Wright, Research Manager Interim Waste Technology

Publicatlon Date: June 1988
This report was prepared as an account of work sponsored by an agency of the United States Government. Neither the United States Government nor any agency thereof, nor any of their employees, makes any warranty, express or implied, or assumes any legal liability or responsibility for the accuracy, completeness, or usefulness of any information, apparatus, product, or process disclosed, or represents that its use would not infringe privately owned rights. Reference herein to any specific commercial product, process, or service by trade name, trademark, manufacturer, or otherwise does not necessarily constitute or imply its endorsement, recommendation, or favoring by the United States Government or any agency thereof. The views and opinions of authors expressed herein do not necessarily state or reflect those of the United States Government or any agency thereof.

\section{E. I. du Pont de Nemours \& Co. Savannah River Laboratory \\ Aiken, SC 29808}


DO MU MUTORLW THIS PAGE

w....... 


\section{ABSTRACT}

A computer model has been developed to predict radiolytic gas generation and transport within Transuranic (TRU) waste drums and surrounding enclosures. Gas generation from the radiolytic decomposition of organic material contaminated with plutonium is modeled and the concentrations of gas throughout the waste drum and enclosures are determined using a diffusional transport model. The model accurately reproduces experimentally measured gas concentrations. With polyethylene waste in unvented drums, the model predicts that the concentration of hydrogen gas can exceed 4 mole percent (1ower flammable limit) with only about 5 curies of plutonium. If the drum 1 iner is punctured and an unrestricted $0.75^{\prime \prime}$ carbon composite filter vent is installed in the drum lid, the plutonium loading $c$ an be increased to $240 \mathrm{Ci}$ without generating flammable gas mixtures. Larger diameter filters can be used to increase the curie loading. The model has been used to show that shipments of $1000 \mathrm{Ci}$ of plutonium-238 contaminated waste from Savannah River to the WIPP site are feasible using the TRUPACT shipping container. 

CONTENTS

Page

Abstract

Introduction

Gas Generation Model

Gas Transport Model

Model Parameters

Simulation Results and Model Validation

Application To SRP TRU Waste

Analysis of TRU Waste Shipment to WIPP

Conclusions

References

Figures $1-17$

Numerical Methods 
LIST OF TABLES

$\underline{\text { Page }}$

1 Gas Generation Coefficients 15

2 Barrier Gas Permeabilities (SI Units) 16

3 Barrier Gas Permeabilities (English Units) 16

4 Gas Diffusion Coefficients $\quad 17$

5 Physical Parameters for Typical 55-Gallon Waste Drum 17

6 Isotopic Composition of LANL Heat-Source Pu-238 19 


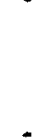


1 Schematic representation of TRU waste drum 32

2 Carbon composite filter vent

3 Measured and model predicted pressures within the drum head space for SRP TRU Waste Drum No. 120

4 Measured and model predicted concentrations of oxygen and hydrogen gas within the head space for SRP TRU Waste Drum No. 120

5 Measured and model predicted concentrations of oxygen and hydrogen gas within the head space for LANL TRU Waste Drum BFB-114

6 Measured and model predicted concentrations of oxygen and hydrogen gas within the drum liner for LANL TRU Waste Drum BFB-114

7 Measured and model predicted concentrations of oxygen and hydrogen gas within the drum head space for LANL TRU Waste Drum BFB-112

8 Model predictions of the steady state hydrogen gas concentration within the drum liner and head space for an unvented TRU waste drum containing polyethylene waste

9 Model simulation of SAIC diffusion experiments using a $0.75^{\prime \prime}$ carbon composite filter vent without a cover

10 Model predictions of the steady state hydrogen gas concentration within the drum liner and head space for a TRU waste drum containing polyethylene waste that is vented with uncovered $0.75^{\prime \prime}$ filters

11 Transient hydrogen gas concentrations within the 1 iner and drum head space for a TRU waste drum with $166 \mathrm{Ci}$ of plutonium on polyethylene waste that is vented with uncovered $0.75^{\prime \prime}$ filters

$$
-8-/-9-
$$


12 Model simulation of SRP diffusion experiments using a $0.75^{\prime \prime}$ carbon composite filter vent without a cover

13 Model simulation of SRP diffusion experiments using a $2.0^{\prime \prime}$ carbon composite filter vent without a cover

14 Model simulation of the pressure within the TRUPACT shipping container with and without a recombiner catalyst present

15 Model simulation of the hydrogen gas concentration within the TRUPACT shipping container with and without a recombiner catalyst present.

16 Model simulation of the hydrogen and oxygen gas concentrations within the drum head space for waste drums within the TRUPACT shipping container without the presence of recombiner catalyst

17 Model simulation of the hydrogen and oxygen gas concentrations within the drum head space for waste drums within the TRUPACT shipping container with recombiner catalyst present 


\section{A COMPUTER MODEL OF GAS GENERATION AND TRANSPORT WITHIN}

TRU WASTE DRUMS

\section{INTRODUCTION}

The incidence of alpha radiation on organic material in transuranic (TRU) waste decomposes it into gaseous products. Oxygen is consumed and hydrogen, carbon monoxide, and carbon dioxide are produced by these radiolysis reactions. Hydrogen generation during the storage and transportation of TRU waste drums may create hazardous conditions. To assist in evaluating the effect of radiolytic gas production at the Savannah River Plant ( $S R P$ ), a computer model has been developed to predict the radio1ytic generation and diffusional transport of gases within drums of TRU waste. The computer model provides the capability of predicting conditions that could potentially lead to the formation of flammable or explosive gas mixtures within the waste drums. The model can be used to assess proposed drum venting methods and is capable of predicting gas concentrations within enclosures that surround the waste drums. This last feature was used to assess the TRUPACT shipping container and safety concerns around the shipment of high curie content TRU waste from SRP to the Waste Isolation Pi lot Plant (WIPP) repository.

The model calculates transient gas concentrations and total pressure as a function of waste composition and plutonium loading. Three volumes within the waste drum are modeled: polyvinylchloride (PVC) bags containing the TRU waste, the volume between the bags and the drum liner, and the volume between the drum liner and the drum lid. The radiolysis is assumed to occur at a constant rate within the PVC bags as a function of waste material composition, curie content, and the particular gas being considered. The gas generation parameters in the model are based on experimental data on radiolysis from plutonium. Because of its high specific activity, plutonium-238 is of primary concern in the management of SRP TRU waste. Other isotopes could be included in the model if adequate gas generation data is available. The gas concentrations are calculated using a simple diffusion model of gas transport through drum barrier materials (PVC bag, polyethylene liner, and rubber gasket) and through free space present in each barrier. The basic components of a TRU waste drum are shown schematically in Figure 1.

The model was validated by simulating experimental data collected at SRP and Los Al amos. When applied to polyethylene waste (worst case waste matrix), the model predicts that hydrogen gas can accumulate to concentrations greater than $4 \%$ (the lower 
limit of flammability) when only about 5 curies of plutonium are present in sealed drums. This limit would place serious restrictions on the management of SRP TRU waste. Therefore, vented drums are being used at SRP to reduce hydrogen gas concentrations in stored waste and allow greater amounts of plutonium to be safely placed in waste drums. The model has been used in the design and evaluation of the SRP filter vents.

A11 DOE sites that generate TRU waste are using some form of venting on the waste drums to prevent the accumulation of flammable gas mixtures. The Savannah River Plant is using carbon-composite filter beds $0.5^{\prime \prime}(1.27 \mathrm{~cm})$ deep and $0.75^{\prime \prime}(1.90 \mathrm{~cm})$ in diameter. The bed is contained in a galvanized carbon steel holder that is screwed into the drum 1 id and drum liner. A schematic representation of the drum filter vent is shown in Figure 2. The carbon composite filter was selected as a vent for SRP drums because of its high efficiency for particulate removal, rugged construction, low cost, and ready availability. The filter effectively prevents dispersal of contaminated particulate matter from the waste drum while allowing gases to freely escape.

The model has been programmed to allow the simulation of gas concentrations with or without the presence of vents in a waste drum. The computer nodel can be used to determine the plutonium loading that can be safely placed in new waste drums to prevent the formation of flammable gas mixtures. Model simulations show that up to 240 curies of plutonium can be placed in waste drums that have the inner liner punctured and contain a $0.75^{\prime \prime}$ diameter filter (with an unrestricted $0.375^{\prime \prime}$ vent hole) in the drum lid without the accumulation of flammable gas mixtures. The curie loading $c a n$ be increased to $500 \mathrm{Ci}$ if the vent diameter is increased to $1.5^{\prime \prime}$.

This report discusses the development of the mathematical model of gas transport and the choice of model parameter values. The numerical treatment is fully explained in an appendix to the report. Comparison of model simulations to existing experimental measurements is made to confirm that the model provides a valid representation of gas transport in actual waste drums. The results of model applications to vented and unvented SRP waste drums are presented along with an evaluation of TRU waste shipments from SRP to the WIPP repository.

\section{GAS GELERATIOA MODEL}

Radiolysis and the resulting gas generation is assumed to occur at a constant rate that is a function of the waste material composition and the level of the radioactivity present for each gaseous species. It is further assumed that the radiolysis reactions are confined to the PVC waste bags. The molar generation 
rate for gas species $k$ within volume element $i, \operatorname{Gr}(i, k)$ moles/s, may be expressed as:

$$
\operatorname{Gr}(i, k)=(\operatorname{curies} P u) * \sum_{j} g(j, k) \frac{\operatorname{mass}(i, j)}{\sum_{j} \operatorname{mass}(i, j)}
$$

In Eq. $1, g(j, k)$ is the radiolytic generation coefficient for gas $k$ from material component $j$ in (moles/s-curie $P u$ ), and mass $(i, j)$ is the mass of material $j$ in the waste mixture within volume $i$. The curies of plutonium is the total curies present in the waste material.

Equation (1) calculates gas generation as the summation of the generation from the individual material components weighted by their mass fraction in the mixture. The gas generation coefficients $g(j, k)$ reported by Kazanjian ( 1 ) were used in the model calculations and are presented in Table 1 of the Model Parameters section below. These coefficients are derived from a series of laboratory experiments measuring gas generation rates under controlled conditions. When more than one coefficient could be applicable, the more conservative value was used to calculate the gas generation rate. The model allows the user to specify a waste material composed of a mixture of cellulose, polyethylene, latex, polyvinylchloride, $\mathrm{Plexiglas,}$ and inert material in any relative proportion.

\section{GAS TRANSPORT MODEL}

Gas transport is assumed to take place by diffusion through the various barriers within the TRU waste drum (Figure 1). Gases are generated (or depleted) in the inner bag volume and diffuse through the PVC bag, the polyethylene liner, and the rubber drum gasket barriers. Any number of waste bags may be present in the drum. The model user specifies the surface areas of the PVC bags, the drum liner, and the drum gasket and the volumes enclosed by these barriers.

A general equation for transient gas transport may be written (with the index $i=1$ to 3 for a single waste drum) as:

$$
v(i) \frac{d[C(i, k)]}{d t}=G r(i, k)+A(i-1) * J(i-1, k)-A(i) * J(i, k)
$$

In Eq. 2, $V(i)$ is the volume $\left(\mathrm{m}^{3}\right)$ of space $i, C(i, k)$ is the concentration (moles $/ \mathrm{m}^{3}$ ) of gas $k$ within the volume, $A(i)$ is the total surface area $\left(\mathrm{m}^{2}\right)$ of the barrier between volume element $i$ and volume element $i+1$, and $J(i, k)$ is the $f l u x$ (moles $/ m^{2}-8$ ) of gas $k$ through the barrier. In writing Eq. (2) for a single waste drum, 
$i=1$ stands for the PVC bag volume and bag surface barrier, $i=2$ represents the polyethylene drum 1 iner and the volume within the liner that is not occupied by waste bags, and $i=3$ is used for the drum gasket and the volume between the drum 1 id and the drum liner. The model calculations as sume that gas generation occurs only in the PVC bags; therefore, $\operatorname{Gr}(2, k)$ and $\operatorname{Gr}(3, k)$ are equal to zero for all k.

Assuming equilibrium between the gases in the drum volumes and within the barrier materials, an expression for the gas flux may be written as:

$$
\begin{aligned}
J(i, k)= & D_{b}(i, k) \frac{[P(i, k)-P(i+1, k)]}{X_{b}(i)} \\
& +D_{0}(i, k) \frac{[C(i, k)-C(i+1, k)]}{X_{0}(i)} Y(i)^{2}
\end{aligned}
$$

In Eq. 3, $D_{b}(i, k)$ is the permeability coefficient (moles/m-s-Pa) for gas $k$ in barrier $i, D_{0}(i, k)$ is the diffusion coefficient $\left(\mathrm{m}^{2} / \mathrm{s}\right)$ for gas $k$ in the barrier pores, $P(i, k)$ is the partial pressure $(\mathrm{Pa})$ of gas $k$ in space $i, X_{b}(i)$ is the transport path length (m) within barrier $i, x_{0}(i)$ is the diffusion path length $(m)$ through openings in barrier $i$, and $Y(i)$ is the porosity of barrier i.

In writing Eq. (3), it is assumed that the gases within the drum are able to diffuse through the barrier materials and through openings that are present in the barriers. That is, gas transport takes place not only by gas permeation and diffusion directly through the material barriers but also by free diffusion through large scale pores or holes in the barriers. As an approximation, the diffusion coefficient $D_{0}(i, k)$ is assumed to be equal to the diffusion coefficient for gas $k$ in air. Including the second term in Eq. (3) allows the model to simulate the presence of filter vents in the drum. However, it was also necessary to include this term to give realistic simulations of drum gas concentrations even when vents were not present. In this case, the term physically represents a lack of sealing or the presence of small holes in the barrier materials. Porosity in the seal on the neck of the PVC bags or around the liner and gasket seals is accounted for by this term. Since the porosities are not known, these values give the model a free parameter for each barrier that can be used to fit experimental data.

When applying Eq. (3), $\mathrm{c}(4, \mathrm{k})$ is the concentration of gas $\mathrm{k}$ in the ambient atmosphere surrounding the drum. The diffusion path length is taken to be equal to the barrier thickness. In reality the barrier pores will have irregular and tortuous paths. The squared porosity term is used to account for the effects of a random pore distribution and pore tortuosity. It can be shown 
that, for a completely random pore distribution at any cross section of the material, squaring the porosity correctly accounts for the change in gas flow path. Alternatively, the tortuosity can be approximated as the reciprocal of the porosity again leading to a squared porosity factor in the transport equation.

The gases considered in this model are: oxygen, nitrogen, carbon monoxide, carbon dioxide, and hydrogen. Oxygen is depleted in the PVC bags by the radiolysis reactions. Carbon monoxide, carbon dioxide, and hydrogen are all generated by the reactions. Nitrogen is a chemically inert species that simply diffuses through the material barriers.

\section{MODEL PARAMETERS}

The basic parameters required for a model simulation are the specification of: 1) Gas generation coefficients, 2) Gas permeabilities through the barrier materials, 3) Gas diffusion coefficients, and 4) Waste drum physical characteristics. The model parameters used in the computations reported here are listed below.

Gas generation coefficients for the materials of interest are given in Table 1. The values were obtained from Kazanjian (1) and converted to be on a basis of curies of plutonium.

\section{TABLE 1}

Gas Generation Coefficients (millimoles/day-curie Pu)

\begin{tabular}{lrrrrrr} 
& \multicolumn{1}{c}{ Cellulose } & Polyethylene & Latex & PVC & Plexiglas \\
\cline { 2 - 3 } Hydrogen & 0.158 & 0.216 & 0.111 & 0.197 & 0.121 \\
Carbon dioxide & 0.089 & 0.021 & 0.013 & 0.026 & 0.155 \\
Carbon monoxide & 0.028 & 0.011 & 0.011 & 0.011 & 0.211 \\
Oxygen & -0.199 & -0.082 & -0.199 & -0.557 & -1.150
\end{tabular}

The coefficients in Table 1 show that the primary radiolysis reactions are the consumption of oxygen and the production of hydrogen. Carbon monoxide and carbon dioxide are generally produced in smaller quantities. As hydrogen is generated, the gas composition in the TRU waste drum may become flammable and present a potential hazard. Table 1 also shows that polyethylene is the worst-case waste material, having both the highest hydrogen generation rate and smallest oxygen depletion rate of the normal waste materials. Flammable gas mixtures accumulate most readily with polyethylene as the waste material. However, other materials have 
similar gas generation characteristics, so that using polyethylene as the worst case material for a safety analysis will yield moderately conservative results.

While the model calculations only consider gas generation from radiolysis, there is evidence that thermal and bacterial decomposition of the organic material in the waste can also produce flammable gases. The parameters appropriate to estimate this source of gas are not well defined. If this information becomes available, it should be incorporated into the model calculations for an added degree of conservatism.

Gas permeabilities through the barrier materials are listed in metric units in Table 2 and in English units in Table 3 (2). Permeability values in English units are used in the computer program since drum parameters are more commonly specified in these units. Styrene-butadiene rubber is assumed to be representative of the drum gasket material.

\section{TABLE 2}

Barrier Gas Permeabilities (millinoles/day-m-kPa) (values nust be multiplied by $10^{-10}$ )

\begin{tabular}{|c|c|c|c|}
\hline & $\begin{array}{l}\text { Polyvinyl- } \\
\text { chloride } \\
\end{array}$ & Polyethylene & $\begin{array}{l}\text { Styrene-But adiene } \\
\text { Rubber }\end{array}$ \\
\hline $\begin{array}{l}\text { Hydrogen } \\
\text { Carbon dioxide }\end{array}$ & $\begin{array}{r}588.5 \\
40.6\end{array}$ & $\begin{array}{r}3648.5 \\
753.2\end{array}$ & $\begin{array}{l}5796.3 \\
1447.6\end{array}$ \\
\hline $\begin{array}{l}\text { Carbon monoxide } \\
\text { Oxygen } \\
\text { Nitrogen }\end{array}$ & $\begin{array}{r}55.9 \\
13.5 \\
3.4\end{array}$ & $\begin{array}{r}7.2 \\
844.4 \\
107.1\end{array}$ & $\begin{array}{r}43.5 \\
868.0 \\
494.3\end{array}$ \\
\hline
\end{tabular}

\section{TABLE 3}

Barrier Gas Perweabilities (1b moles-mil/hr-ft ${ }^{2}$-atm) (values must be multiplied by $10^{-7}$ )

\begin{tabular}{|c|c|c|c|}
\hline & $\begin{array}{l}\text { Polyvinyl- } \\
\text { chloride }\end{array}$ & Polyethylene & $\begin{array}{l}\text { Styrene-Butadiene } \\
\text { Rubber }\end{array}$ \\
\hline $\begin{array}{l}\text { Hydrogen } \\
\text { Carbon dioxide } \\
\text { Carbon monoxide } \\
\text { Oxygen } \\
\text { Nitrogen }\end{array}$ & $\begin{array}{l}20.0 \\
1.38 \\
1.90 \\
0.460 \\
0.116\end{array}$ & $\begin{array}{c}124.0 \\
25.6 \\
0.244 \\
28.7 \\
3.64\end{array}$ & $\begin{array}{c}197.0 \\
49.2 \\
1.48 \\
29.5 \\
16.8\end{array}$ \\
\hline
\end{tabular}


The permeabilities indicate that the light hydrogen gas will diffuse through the barrier materials faster than the other heavier gases. This is also true for free diffusion through the material pores. Diffusion coefficients for each of the gases in air at $25^{\circ} \mathrm{C}$ are 1 isted in Table 4.

\section{TABLE 4}

Gas Diffusion Coefficients $\left(\mathrm{cm}^{2} / \mathrm{s}\right)$

$\begin{array}{ll}\text { Hydrogen } & 0.611 \\ \text { Carbon dioxide } & 0.138 \\ \text { Carbon monoxide } & 0.185 \\ \text { Oxygen } & 0.178 \\ \text { Nitrogen } & 0.181\end{array}$

The parameters used in the model calculations to specify the waste drum physical characteristics are listed in Table 5. These parameters represent typical values for a 55-gallon waste drum having an overall void volume of $70 \%$. Values are given in metric units and in the more commonly specified English units. These parameters can be easily modified when running the program to simulate other configurations.

\section{TABLE 5}

Physical Parameters for Typical 55-Gallon Waste Drum

\begin{tabular}{|c|c|c|c|}
\hline & $\begin{array}{l}\text { PVC } \\
\text { Waste Bag }\end{array}$ & $\begin{array}{l}\text { Pol yethylene } \\
\text { Liner }\end{array}$ & Rubber Gasket \\
\hline Number in drum & 17 & 1 & 1 \\
\hline $\begin{aligned} \text { Void volume } & \left(\mathrm{m}^{3}\right) \\
& \left(\mathrm{ft} \mathrm{t}^{3}\right)\end{aligned}$ & $\begin{array}{l}0.0057 \\
0.20\end{array}$ & $\begin{array}{l}0.028 \\
1.00\end{array}$ & $\begin{array}{l}0.021 \\
0.75\end{array}$ \\
\hline $\begin{aligned} \text { Surface area } & \left(\mathrm{m}^{2}\right) \\
& \left(\mathrm{ft} \mathrm{t}^{2}\right)\end{aligned}$ & $\begin{array}{l}0.40 \\
4.30\end{array}$ & $\begin{array}{r}1.95 \\
21.00\end{array}$ & $\begin{array}{l}0.017 \\
0.18\end{array}$ \\
\hline $\begin{aligned} \text { Thickness } & (\mathrm{mm}) \\
& (\mathrm{mi} 1)\end{aligned}$ & $\begin{array}{l}0.51 \\
20.0\end{array}$ & $\begin{array}{l}2.29 \\
90.0\end{array}$ & $\begin{array}{l}9.53 \\
375.0\end{array}$ \\
\hline Porosity $(x 1000)$ & 0.125 & 1.25 & $6.0-8.5$ \\
\hline
\end{tabular}


The volume listed under the drum liner is the void volume within the liner that is not occupied by the waste bags. The volume listed under the gasket is the volume between the rubber gasket and the drum 1 id. This volume is referred to as the drum head space in the following discussion. Porosity values represent the fractional part of the barrier material that is assumed to be free void space where the gas transport takes place by free diffusion rather than by permeation and diffusion. The porosity values represent the fractional parts of the material that are open area.

\section{SIMULATION RESULTS AND MODEL VALIDATION}

The results of model simulations were compared to data collected on the gas composition within TRU waste drums at the Savannah River Laboratory (SRL) and at the Los Alamos National Laboratory (LANL). The SRL data (3) was obtained during a four year experimental study in which gas concentrations were monitored within four high-activity TRU waste drums. These were lined 55-gallon drums containing typical cabinet waste from a Pu-238 finishing facility. Drum gaskets were nonporous and a caulking compound was used to seal the gaskets to the drum lids and to seal the drum liners. Gas samples were collected from the air space between the drum 1 iner and the drum itself. Drums were monitored for: temperature, pressure, oxygen, hydrogen, carbon monoxide, carbon dioxide, nitrogen, nitrous oxide, and total hydrocarbons. The waste composition was well documented and the model was able to predict gas concentrations in the drums within the accuracy of the experimental measurements.

A model simulation was run for Drum No. 120 of the SRL study. This waste drum contained plastic, rubber, and metal contaminated with $112.6 \mathrm{Ci}$ ( $6.7 \mathrm{grams}$ ) of $\mathrm{Pu}-238,0.7 \mathrm{Ci}$ of $\mathrm{Pu}-239$, and $0.06 \mathrm{mCi}$ of U-235. Figure 3 shows a model simulation of total pressure in the drum head space compared to experimentally measured values. The diffusion model predicts a smooth pressure rise to about 4.5 psig at 1500 days while experimentally an initial pressure decrease (possibly from rapid oxygen depletion) followed by an irregular pressure rise was observed. The data plotted in Fig. 3 have been corrected to $25^{\circ} \mathrm{C}$ to remove changes arising from temperature variation alone; however, much of the variation still appears to follow an annual pattern. These fluctuations may arise from variation in barrier permeabilities with ambient temperature or from pressure changes. No attempt was made to include such effects in the model.

Model predictions of the hydrogen and oxygen concentrations within the drum head space are shown in Fig. 4. Hydrogen gas accumulates rapidly in the drum head space while oxygen is depleted. These trends are reproduced by the model simulation. Both curves show essentially steady state behavior after about one year of gas generation. Again, the strong fluctuations in the 
experimental data may be temperature or pressure dependent. At about day 1000 , the experimentally observed hydrogen gas concentration and total pressure suddenly increase. The waste material may have been disturbed or the integrity of a waste bag or the drum 1 iner may have been compromised at this point.

The parameters given in Table 5 were used to obtain the model results plotted in Fig. 3 and Fig. 4. Using the largest gasket porosity gave an improved fit to the SRL experimental data. All of the model parameters (including waste composition and drum physical parameters) were based on the available experimental data (3) except for the porosity values which were adjusted to fit the experimental results.

Model simulations were also made for several drums from a series of experiments on gas generation in TRU waste conducted at LANL $(4,5)$. Gas concentrations in eight drums of TRU waste from Pu-238 heat-source production were monitored for about one year. The isotopic composition of the waste is given in Table 6 . As with the SRP drums, the drum lids and inner liners were sealed. The experiments were designed to evaluate the effectiveness of carbon-composite filters in maintaining safe hydrogen gas concentrations within the drums and drums were tested both with and without filter vents. The drums and the carbon-composite filter vent were similar in design to those in use at SRP.

Results from the simulation of waste drum BFB-114 are presented in Fig. 5 and Fig. 6. Experimental data is shown by 1 ines connecting the plotted data points while model predictions are indicated by smooth curves. Figure 5 shows model predictions of hydrogen and oxygen gas concentrations within the drum head space while the same predictions for the drum liner are shown in Fig. 6. The waste drum was initially sealed and a filter vent in

\section{TABLE 6}

Isotopic Composition of LANL Heat-Source $\mathrm{Pu}-238$

\begin{tabular}{lr} 
Isotope & Weight Percent \\
\cline { 3 - 3 } Pu-238 & 80.0 \\
Pu-239 & 16.3 \\
Pu-240 & 3.0 \\
Pu-241 & 0.6 \\
Pu-242 & 0.1
\end{tabular}


the drum lid was opened 112 days after preparation. This waste drum contained $218.4 \mathrm{Ci}$ (15.6 grams) of $\mathrm{Pu}-238$ which was the highest curie loading in the LANL study. The composition of the drum waste was not well defined. Therefore, the composition used in model calculations was adjusted to reproduce the reported total and hydrogen gas generation values. The drum parameter values listed in Table 5 were used with the lowest gasket porosity improving the fit for the LANL data. Since several different gasket materials have been commonly used at the various DOE sites, the apparent difference in porosity between SRP and LANL drum gaskets is not surprising.

The model is able to accurately simulate hydrogen and oxygen concentrations within both volumes over the entire experimental time period. Gas concentrations within the drum 1 iner are only slightly different from those in the drum head space. With a sealed drum, the hydrogen gas concentration exceeds $4 \%$ within 20 days, while oxygen is rapidly depleted. Opening the drum lid vent significantly reduces the hydrogen gas concentration. However; flammable gas concentrations persist. Based on data in the LANL report (4), the filter was modeled as a carbon bed $1.9 \mathrm{~cm}$ in diameter and $1.27 \mathrm{~cm}$ long with a low bed porosity of 0.10 .

In Fig. 7, another drum from the Los Alamos study containing $16.8 \mathrm{Ci}(1.2 \mathrm{gram})$ of plutonium-238 is simulated. The drum was initially vented to the atmosphere and the filter vent was closed 123 days after preparation. Using the same gasket porosity as with the other LANL drum, the model is able to closely track gas concentrations within the drum. The total and hydrogen gas generation rates were again reproduced by adjusting the waste composition. Even with this low curie content, the drum contains a hydrogen gas concentration greater than $4 \%$ about 150 days after the vent is closed. When the drum was vented, hydrogen gas did not accumulate.

\section{APPLICATION TO SRP TRO WASTE}

The experimental studies discussed above show that flammable gas mixtures will accumulate in TRU waste drums with relatively low plutonium loads. To ensure adequate conservatism for safety analysis, a limit of $4 \%$ (lower flammable limit) is placed on the hydrogen gas concentration allowed within waste drums. Limiting the curie loading in sealed waste drums such that flammable gas mixtures will not accumulate places severe restrictions on the management of SRP TRU waste. Therefore, the use of vented drums was proposed as a method of reducing hydrogen gas concentrations in stored waste to allow greater amounts of plutonium to be handled safely. 
Model simulations were run to assess the effect of venting on SRP TRU waste drums. Figure 8 presents a plot of model predictions of the steady state hydrogen gas concentrations within the drum 1 iner (Liner) and drum head space (Drum) for an unvented drum containing polyethylene waste. Plutonium loadings greater than $5 \mathrm{Ci}$ in the waste material yield concentrations of hydrogen gas exceeding 4 mole (or volume) \% in both the liner and drum. The hydrogen concentrations shown in Fig. 8 are similar to the values observed during the SRP experimental study (3). The experiments and simulations demonstrate that high concentrations of hydrogen can be realized in actual waste drums. Model calculations indicate that with a loading of $10 \mathrm{Ci}$ in an unvented drum, flammable gas accumulates inside the drum liner in 163 days and inside the head space within 185 days.

SRP began the routine use of drum vents for newly generated waste in 1986. As discussed above, the $0.75^{\prime \prime}(1.9 \mathrm{~cm})$ diameter carbon composite filter illustrated in Fig. 2 was selected as a vent for SRP waste drums. Experiments to evaluate different designs of the filter casing were conducted by Science Applications International Co. (SAIC) by filling a vented 55 gallon drum with a mixture of 4 mole \% hydrogen in air and monitoring the decrease in hydrogen concentration within the drum over time. It was found that the original vent design, with a ridged-cap over the filter, could adequately vent the gas generated from about $50 \mathrm{Ci}$ of plutonium in the drum. The best venting was obtained with a filter housing having a $0.95 \mathrm{~cm}$ diameter inlet and a $0.32 \mathrm{~cm}$ diameter outlet port with no ridgecap over the case. The SAIC experimental results can be used to determine an effective filter bed porosity. Model simulations of 6 SAIC experiments (6) on the uncapped filter using a bed porosity of 0.51 are presented in Fig. 9. The model accurately reproduces the experimental data. Therefore, using the experimentally determined porosity, model simulations of filter vent performance in actual waste drums $c$ an be conducted with confidence.

Figure 10 shows model predictions of the steady state hydrogen gas concentration within the drum liner and the drum head space when filter vents ( $0.75^{\prime \prime}$ uncapped) are present in both the 1 iner and drum lid. Compared to an unvented drum (Fig. 8), the hydrogen gas concentrations are significantly lower. With venting, up to $133 \mathrm{Ci}$ of plutonium can be placed in a drum of polyethylene waste before the hydrogen flammable limit is exceeded in the 1 iner. If the drum liner is punctured and fully vented rather than filtered, the gas transport becomes 1 imited by the 1 id filter capacity and the drum loading could be increased to $240 \mathrm{Ci}$ before flammable gases accumulate. Of course, the barrier to particulate transport between the drum liner and head space has been removed. 
A model calculation of the transient hydrogen gas concentration within the drum liner and head space for a vented waste drum containing $166 \mathrm{Ci}$ of plutonium is shown in Figure 11. Steady state concentrations are quickly reached and, with a plutonium loading 25\% greater than the established limit, a flammable hydrogen concentration occurs within the drum liner after only 15 days. Therefore, when using the 0.75" filters, careful monitoring of the waste content is required to avoid exceeding the $133 \mathrm{Ci}$ loading limit.

It is desirable for SRP TRU waste drums to be able to contain up to $500 \mathrm{Ci}$ of plutonium. To assess whether the $0.75^{\prime \prime}$ filter was adequate for this level of containment and to assess other filter designs, a series of experiments were conducted by SRP and SRL at the Du Pont Explosion Test Center at the Chamber's Works. Hydrogen gas was bled into a 4170-cc cylindrical vessel containing a filter in one end at rates of $1.0 \mathrm{cc} / \mathrm{min}$ and $2.5 \mathrm{cc} / \mathrm{min}$ to $\mathrm{simulate}$ the gas generation from up to $500 \mathrm{Ci}$ of plutonium.

Model predictions and experimental data for five hours of testing with a $0.75^{\prime \prime}$ diameter filter at a hydrogen addition rate of $1.0 \mathrm{cc} / \mathrm{min}$ (equivalent to approximately $200 \mathrm{Ci}$ of plutonium) are presented in Fig. 12. The model accurately predicted the experimental results and both indicated that a steady state concentration of approximately 4 mole \% hydrogen would be reached. Model predictions and experimental results also showed that a concentration of 4 mole \% hydrogen was exceeded within a few hours when a 0.75 " diameter filter was used with a gas addition rate of $2.5 \mathrm{cc} / \mathrm{min}$. A steady state concentration of 10 mole percent hydrogen was observed at 18 hours for this configuration while the model predicted a steady state concentration of 12 mole \%. Model predictions and experimental data for five hours of testing with a $2.0^{\prime \prime}$ diameter filter at a hydrogen addition rate of $2.5 \mathrm{cc} / \mathrm{min}$ (equivalent to approximately $500 \mathrm{Ci}$ of plutonium) are presented in Fig. 13. The model predicted that a steady state concentration of about $1.7 \%$ hydrogen would be reached after three hours and experimental results confirmed the model predictions. Therefore, a 2.0 " carbon composite filter would provide sufficient venting for a waste drum containing up to $500 \mathrm{Ci}$ of plutonium. Model calculations indicated that a 1.5" filter would also be adequate.

Since it is unlikely that SRP TRU waste will consist entirely of polyethylene, the calculations reported here should give somewhat conservative estimates of the maximum plutonium loadings that can be placed in waste drums. Calculations for other waste materials and operating parameters can easily be made with the computer model if desired. 


\section{ANALYSIS OF TRU WASTE SHIPMENT TO WIPP}

The national DOE program provides for the ultimate disposal of all TRU waste from within the DOE complex at the WIPP repository near Carlsbad, New Mexico. To transport TRU waste from generator sites to WIPP, a Transuranic Package Transporter (TRUPACT) shipping container is being designed (7-9). The current design, TRUPACT-II, is an unvented rectangular vessel capable of holding 36 55-gallon waste drums that can ride on either a railcar or flatbed truck. DOT regulations forbid reliance on continuous venting to prevent the accumulation of flammable gases within shipping vessels. Therefore, because of its relatively high gas generation rates, high curie content $\mathrm{Pu}-238$ contaminated TRU waste from SRP presents a particular difficulty in providing safe transportation to WIPP.

The current DOE assessment is that the TRUPACT can safely transport on the order of 1000 alpha-curies per shipment. To conduct an independent evaluation, the SRL model was used to determine pressure increases and gas concentrations within the TRUPACT container. While the gas generation rates used in the model are well supported by laboratory data (1), higher values have appeared in the literature ( 3 ). It has also been suggested that gas generation from thermal degradation and bacterial decomposition of organic material in the waste may contribute to hydrogen gas formation. Therefore, to increase the conservatism in this assessment, gas generation rates were multiplied by a factor of four where one factor of two is intended to account for the possibility of higher radiolytic generation rates and the other factor of two accounts for generation from other sources. This results in a total gas generation (or G) factor of 3.46 molecules of gas produced per $100 \mathrm{eV}$ of absorbed alpha radiation.

DOE has proposed to control the vessel pressure and hydrogen gas concentration by placing hydrogen recombiner catalyst inside the TRUPACT. The catalyst acts to promote the reaction between hydrogen and oxygen to produce water. Therefore, as long as both gases are present, hydrogen will not accumulate within the TRUPACT and, since the reaction consumes 1.5 moles of gas for each mole of water produced, the pressure is reduced. When the oxygen is depleted, hydrogen gas will buildup; however, the gas mixture will not be flammable. The SRL model has been programmed to simulate the presence of a recombiner catalyst.

* As this report was being prepared, the DOE requested bids for the design and construction of a TRUPACT-II container that may be substantially different from the unit assumed in these sample calculations. 
Figure 14 presents model calculations of the expected pressure increase within the TRUPACT container over a one year period when $1000 \mathrm{Ci}$ of plutonium is evenly distributed between 36 drums. Each drum is assumed to be vented with $0.75^{\prime \prime}$ filters in the drum liner and in the drum 1 id and to contain polyethylene waste. Other drum parameters are as 1 isted in Table 5. The total interior volume of the TRUPACT shipping container is $668 \mathrm{ft}^{3}(7,8)$. The 36 waste drums occupy about $265 \mathrm{ft}^{3}$ of the space and dunnage packing will occupy $334 \mathrm{ft}^{3}$ of the remaining volume. However, the dunnage material is relatively porous and the total void volume within the TRUPACT container was conservatively estimated to be about $200 \mathrm{ft}^{3}$ using a $40 \%$ dunnage porosity. Calculations were performed both with (lower curve) and without (upper curve) recombiner catalyst in the TRUPACT. The break in the recombiner pressure curve occurs when oxygen within the TRUPACT is depleted. The calculations assume a well sealed vessel and $100 \%$ catalyst efficiency.

DOT regulations require that the vessel be able to hold the drums without exceeding its maximum normal operating pressure for one year which is $18.5 \mathrm{psi}$ for the TRUPACT-II design (9). Since some allowance must be made for pressure increases from changes in the ambient temperature and pressure and from water vapor, it is reasonable to allow about $13.5 \mathrm{psi}$ for gas generation. Thus, the SRL model prediction of a 9.2 psi pressure increase indicates that shipments of $1000 \mathrm{Ci}$ loads will safely meet the established regulations. However, the TRUPACT is unable to accommodate any significant increase in load in its present design. About 100 TRUPACT shipments per year from SRP to WIPP will be required over a 25 -year waste disposal period. The $1000 \mathrm{Ci}$ limit makes package curie content as significant as total volune in determining the number of shipments from SRP to WIPP. This implies that some inventory management problems may arise in controlling the TRUPACT shipments. The model calculations also indicate that including the recombiner catalyst does not produce a lower container pressure after one year. This is because model simulations show that oxygen is essentially depleted within the container in less than one year even without the catalyst present and both solutions converge to the same limit.

Figure 15 shows model calculations of the hydrogen gas concentration within the TRUPACT when recombiner catalyst is present (lower curve) and when it is not (upper curve). The catalyst is active until oxygen is depleted in about 120 days at which time hydrogen gas begins to accumulate within the TRUPACT. Without the recombiner, a flammable gas mixture is generated at about 25 days. However, DOT regulations only require that a flammable mixture not occur within twice the normal shipping time. Since the shipping time by truck from SRP to WIPP is about 1.5 days, regulatory standards are met without the recombiner. An adequate margin of safety is also provided for cases where the catalyst is used but is 
deactivated or accidentally omitted, or the shipment is delayed for several days. Rail transportation nominally takes 18 days and would require the presence of recombiner catalyst to meet safety standards.

The concentration of hydrogen and oxygen within the waste drums inside of the TRUPACT are plotted in Fig. 16 for the case where no recombiner catalyst is present. A steady depletion of oxygen and generation of hydrogen is observed. Flammable gas mixtures are present from day 20 until day 201 when the oxygen concentration is below the flammable limit. As the concentration of oxygen approaches zero, the TRUPACT pressure curves shown in Fig. 14 converge. Calculations of drum gas concentrations in the presence of recombiner catalyst are shown in Fig. 17. A steady state hydrogen concentration of about $1.6 \%$ is established in the drums until oxygen is depleted. The potential does exist for producing a transient flammable gas mixture when the shipping container is opened at the WIPP site.

\section{CONCLUSIONS}

A model of radiolytic gas generation and gas transport within TRU waste drums has been developed and validated by simulating experimental data collected at SRL and LANL over a wide range of conditions. These data were used to determine typical porosity values for waste bags, drum liners, and drum gaskets. Using a consistent set of parameters, the model is able to predict gas concentrations in TRU waste drums within the accuracy of the experimental data. The model has been structured to report steady state gas concentrations without performing a full transient calculation which allows the user to immediately tell whether a particular drum configuration will eventually exceed safety limits. The model can be used to evaluate the effectiveness of filter vents in controlling the atmosphere within TRU waste drums.

Model development proceeded through several stages. The initial version assumed that gas transport occurred only through permeation and diffusion in the barrier materials. This model was incapable of predicting the experimentally observed gas concentrations within drum spaces outside of the PVC waste bags and unrealistically high pressures were predicted within all drum volumes. To correct this deficiency, the model was extended to include the presence of macro-pores in the barriers that would allow for additional gas transport. At first, gas transport through these pores was assumed to occur by pressure induced flow. While this model gave improved results, the total pore area that was required was quite small implying that the gas transport might actually occur by free diffusion through the pores rather than by a flow mechanism. 
The final version of the transport model assumes a combination of gas transport through permeation of the barrier materials and by free diffusion through large scale pores in the barrier materials.

The model has been applied to SRP TRU waste to predict a maximum plutonium loading that can be safely placed in newly generated waste drums without the accumulation of flammable gas mixtures. In the worst case, with unvented waste drums and polyethylene waste, an inventory of less than $5 \mathrm{Ci}$ of plutonium is sufficient to generate hydrogen gas concentrations greater than the $4 \%$ by volume limit. This curie loading limit would be very restrictive for SRP operations.

Model calculations have also been made to demonstrate the efficiency of drum venting as a method to reduce hydrogen gas concentrations in TRU waste drums. With $0.75^{\prime \prime}$ diameter vents in both the drum liner and the drum $1 i d$, it should be possible to safely store from 133 to $240 \mathrm{Ci}$ of plutonium without accumulating flammable gas mixtures. By using 1.5" diameter filter vents, the maximum loading can be increased to 500 curies. Therefore, drums vented through carbon composite filters will be used at SRP.

The model has been used to assess the safety factors inherent in shipping drums of TRU waste from SRP to the WIPP repository using the TRUPACT shipping container. Model analys is indicates that safety considerations are adequate to transport loads on the order of 1000 curies. The curie limit arises from the regulatory requirement that the shipping vessel be capable of containing the pressure buildup from gas generation over the time period of one year. Since the nominal shipping time from SRP to WIPP is only a few days by truck or several weeks by rail, the regulation on vessel pressure is quite conservative. The SRL analysis essentially confirms the DOE assessment of the TRUPACT shipping container.

The computer model is available from the author of this report both as the BASIC source code (TRUGAS.BAS) and as a complied program (TRUGAS.EXE) designed to run on IBM Personal Computers. 


\section{RRFERENCES}

1. A. R. Kazanjian, Radiolytic Gas Generation in Plutonium Contaminated Waste Materials. USDOE Report RFP-2469, Rockwell International, Rocky Flats, Colorado (October 1976).

2. A. E. Jones, Mass Transfer - Gas Concentration in TRU Waste Drums II. Memorandum to S. J. Mentrup (June 1985).

3. J. P. Ryan, Radiogenic Gas Accumulation in TRU Waste Storage Drums. USDOE Report DP-1604, E. I. Du Pont de Nemours and Company, Savannah River Laboratory, Aiken, South Carolina (January 1982).

4. A. Zerwekh and J. L. Warren, Gas Generation and Migration Studies Involving Recently Generated Pu-238 Contaminated Waste for the TRU Waste Sampling Program. USDOE Report LA-10732-MS, Los Alamos National Laboratory, Los Alamos, New Mexico (July 1986).

5. T. L. Clements and D. E. Kudera, TRU Waste Sampling Program: Volume II-Gas Generation Studies. JUSDOE Report EGG-WM-6503, EG\&G Idaho, Inc., Idaho Falls, Idaho (August 1985).

6. C. F. Smith, Hydrogen Vent Performance Tests. SAIC-86/1935, Science Applications International Co., Pleasanton, California (October 1986).

7. R. M. Grenier, D. M. Osborne, L. E. Romesberg, and M. M. Warrant (eds), Transuranic Package Transporter, TRUPACT-I, Safety Analys is Report for Packaging (SARP). USDOE Report SAND 83-7077 (TTC-0338), Sandia National Laboratories, Albuquerque, NM (May 1986).

8. J. D. Hurley, J. J. Tappen, D. S. Christensen (eds), TRUPACT-I Implementation P1an. USDOE Report DOE-J IO-003, Joint Integration Office, Albuquerque, NM (September 1985).

9. Design Criteria for the TRUPACT-II Packaging. TN/TRUPACT 86/0012, Transnuclear, Inc., White Plains, NY (1986).

10. D. D. McCracken and W. S. Dorn, Numerical Methods and FORTRAN Programming. John Wiley \& Sons, New York (1964). 
TRU WASTE DRUM

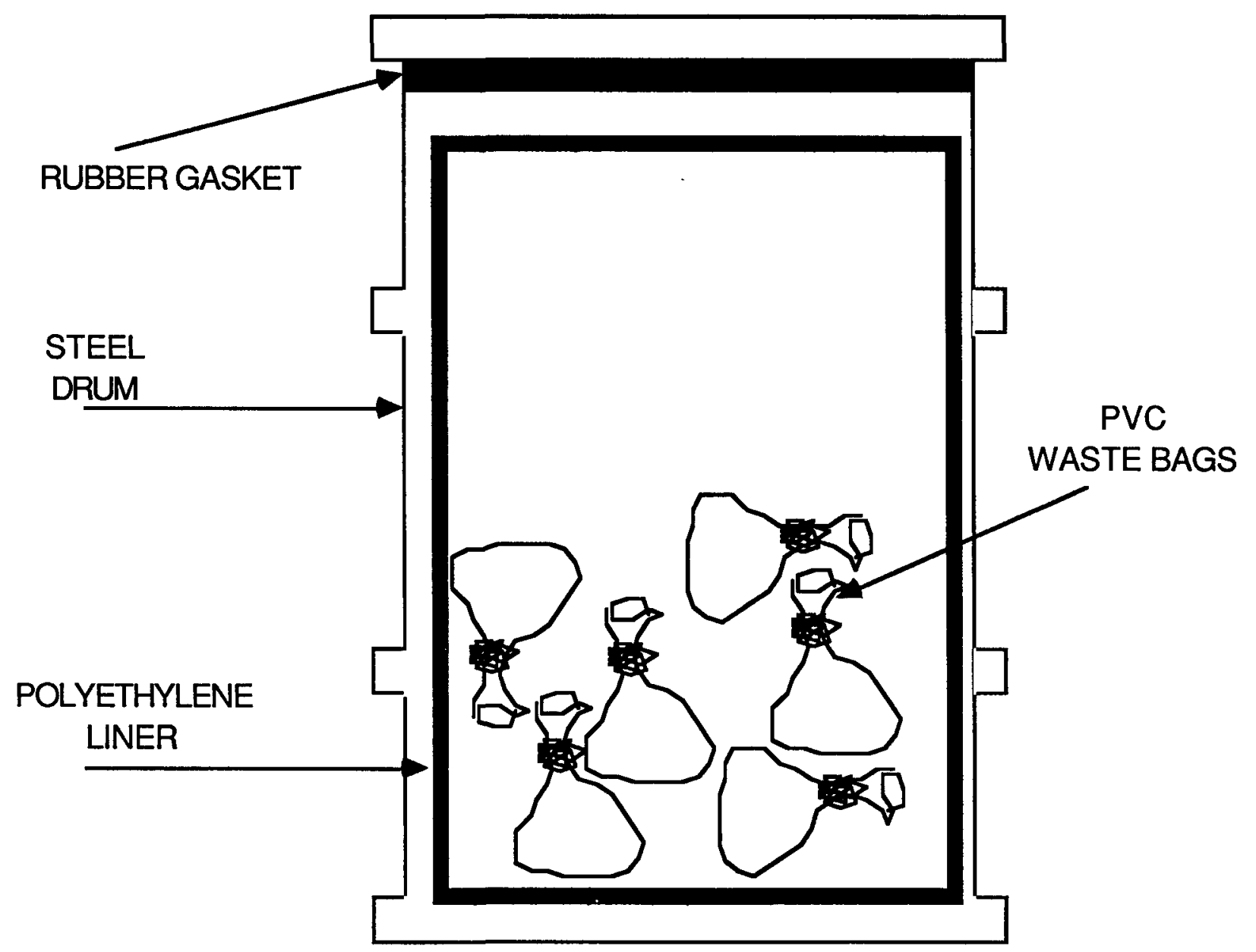

FIGURB 1. Schematic representation of TRU waste drum 


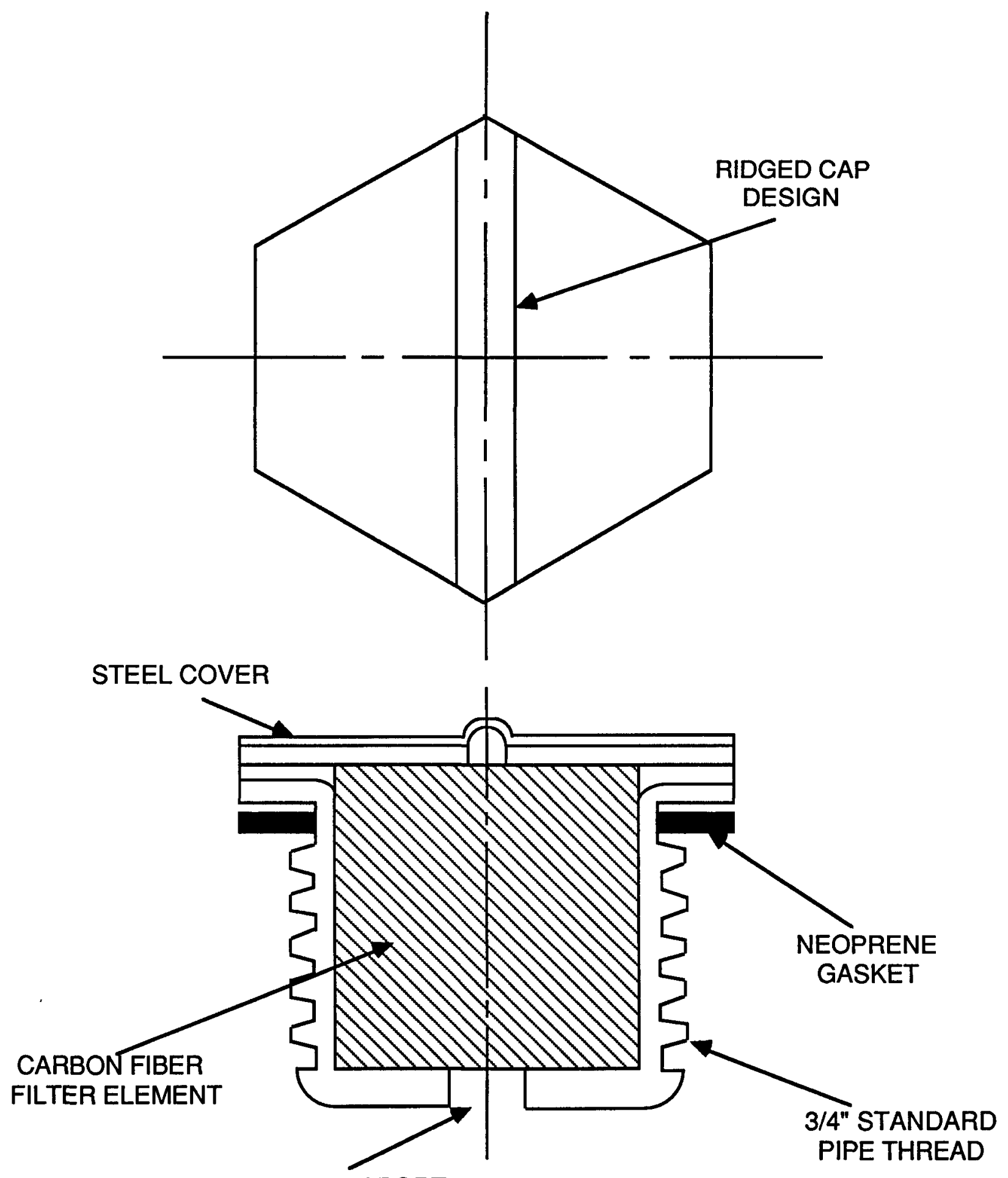

3/8" INLET PORT

FIGURE 2. Carbon composite filter vent 


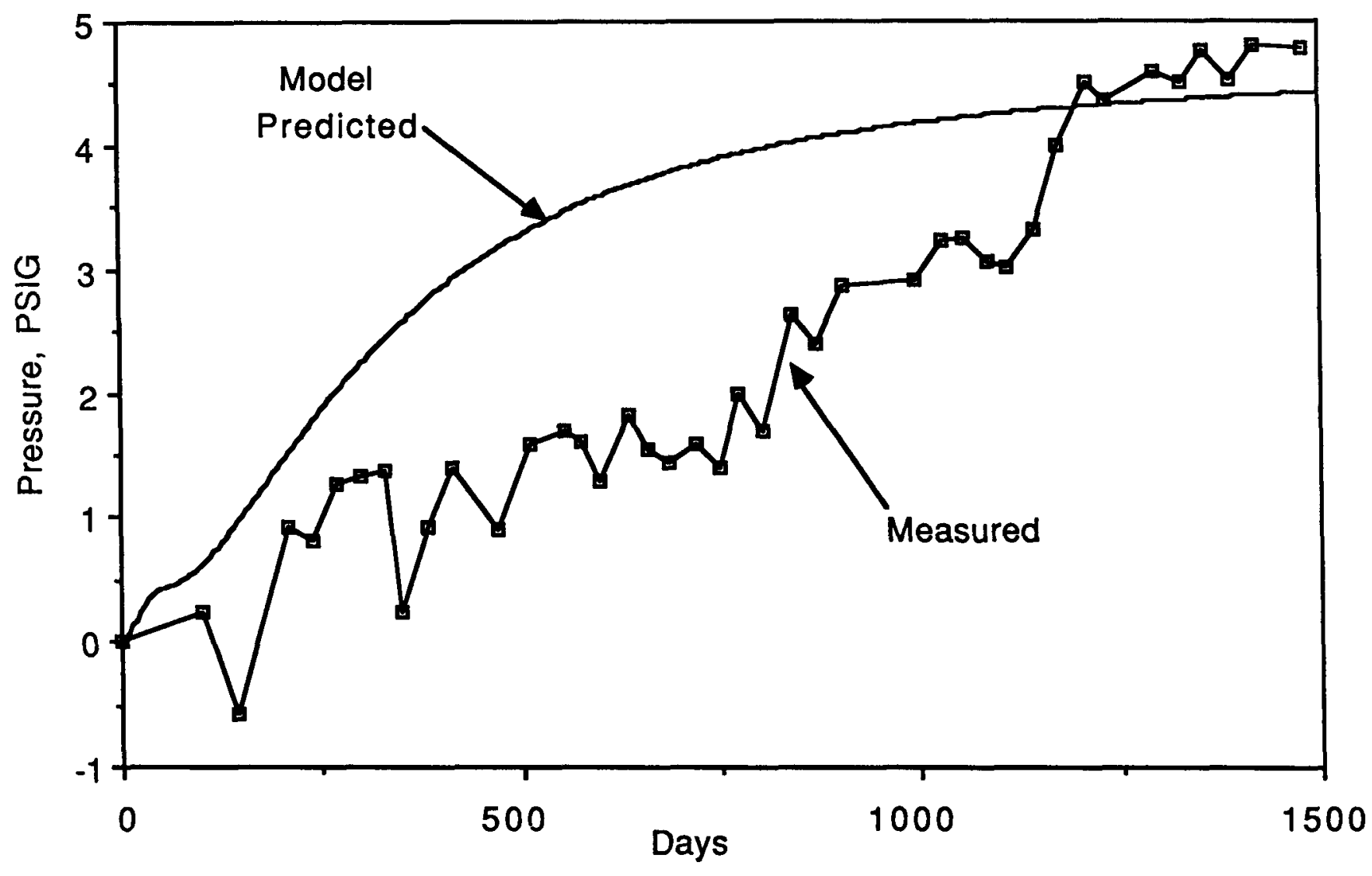

FIGURE 3. Measured and model predicted pressures within the drum head space for SRP TRU Waste Drum Mo. 120 


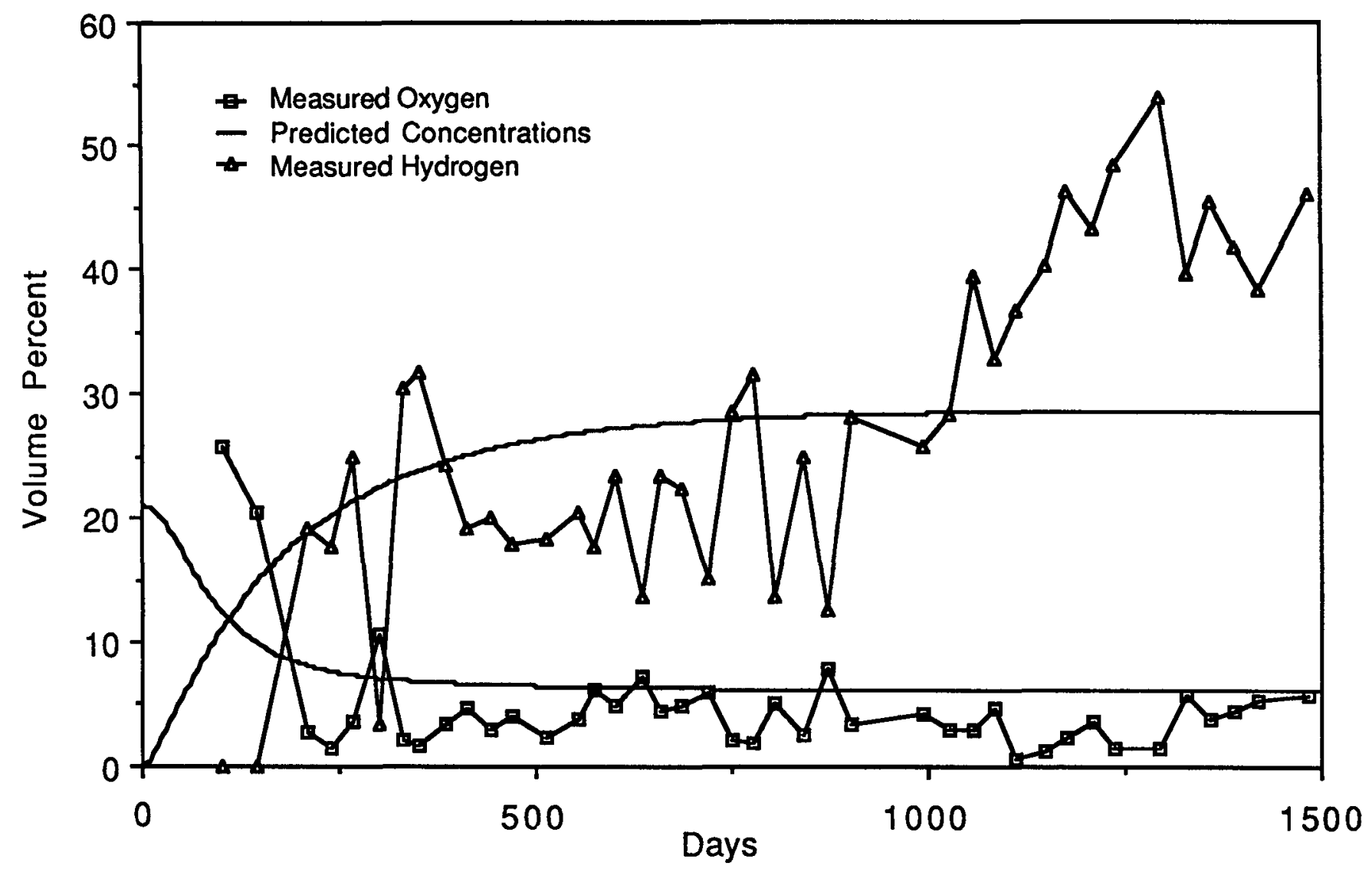

FIGURE 4. Measured and model predicted concentrations of oxygen and hydrogen gas within the head space for SRP TRU Waste Drum No. 120 


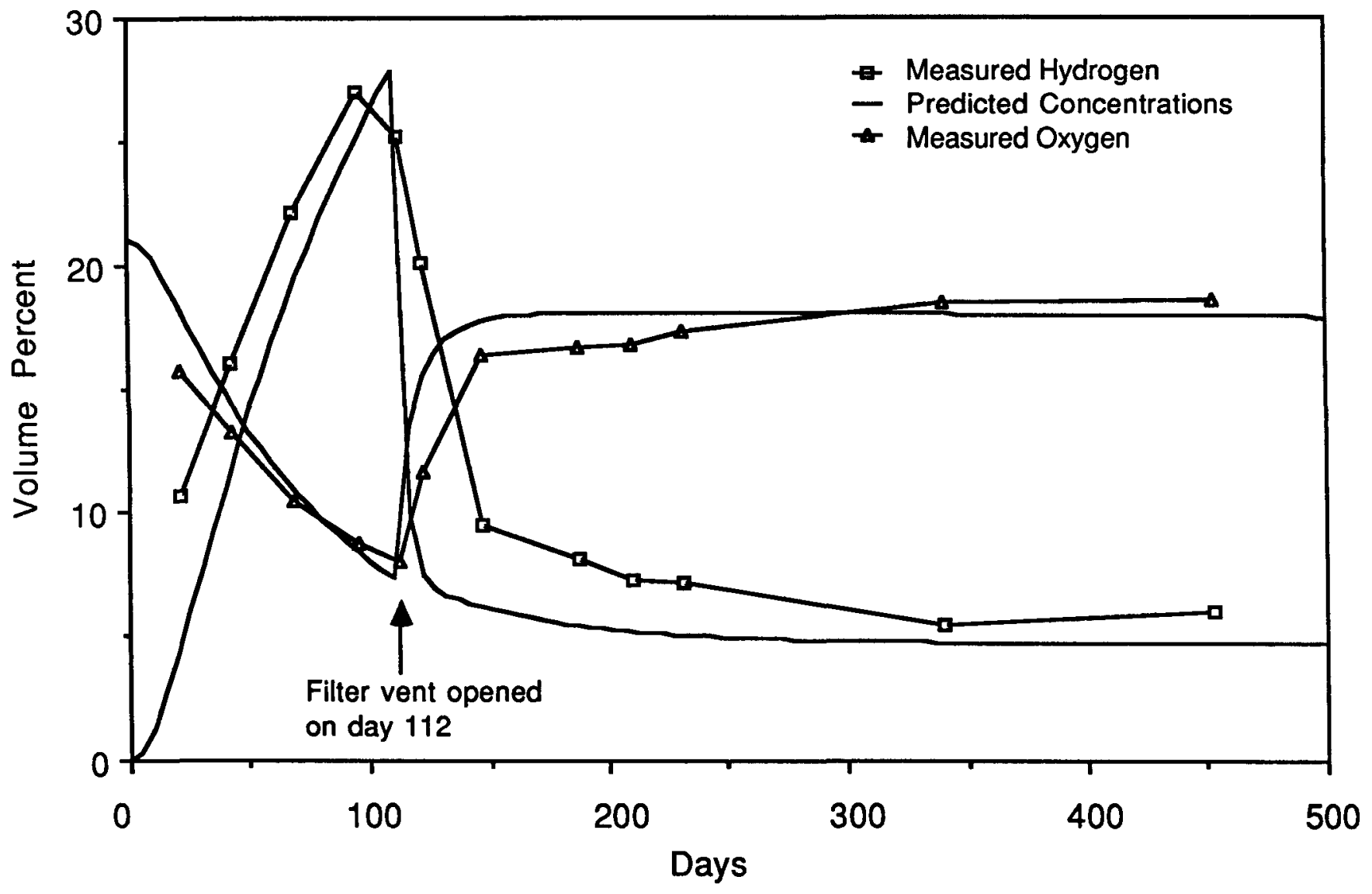

FIGURB 5. Measured and model predicted concentrations of oxygen and hydrogen gas within the head space for LANL TRU Waste Drum No. BFB-114 


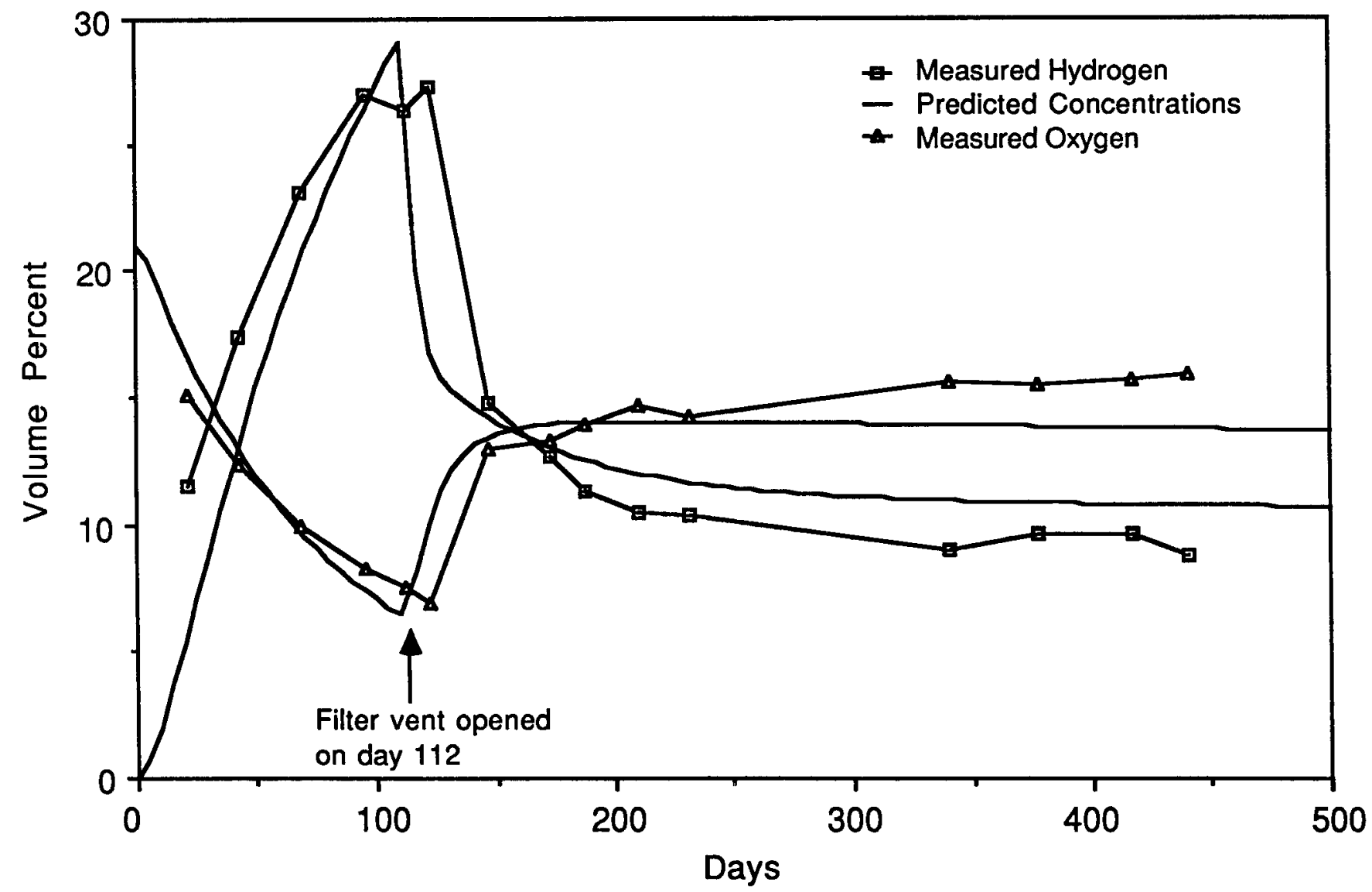

FIGURE 6. Measured and model predicted concentrations of oxygen and hydrogen gas within the drum liner for LANL TRU Waste Drum No. BFB-114 


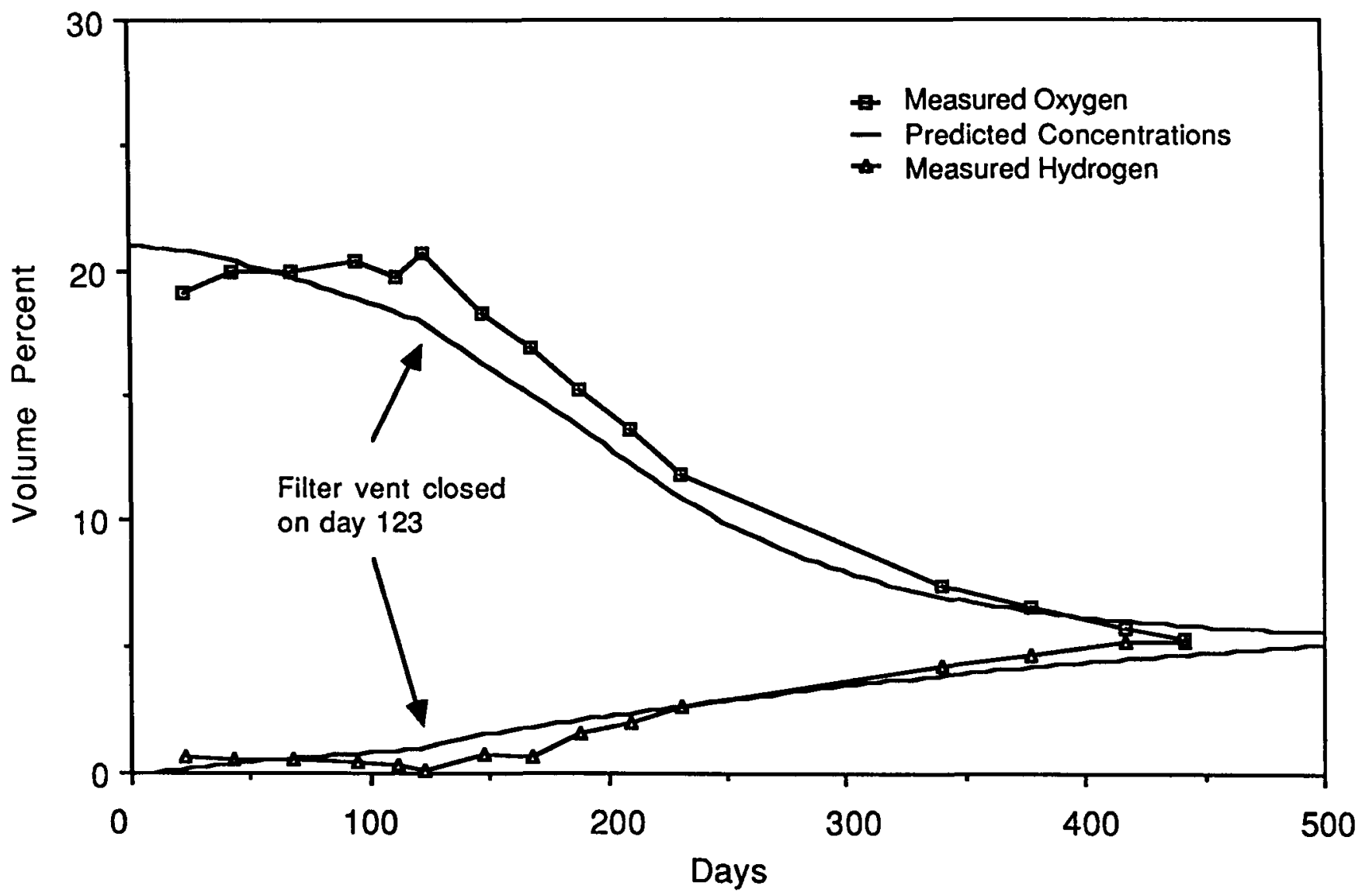

FIGURE 7. Measured and model predicted concentrations of oxygen and hydrogen gas within the drum head space for LANL TRO Waste Drum No. BFB-112 


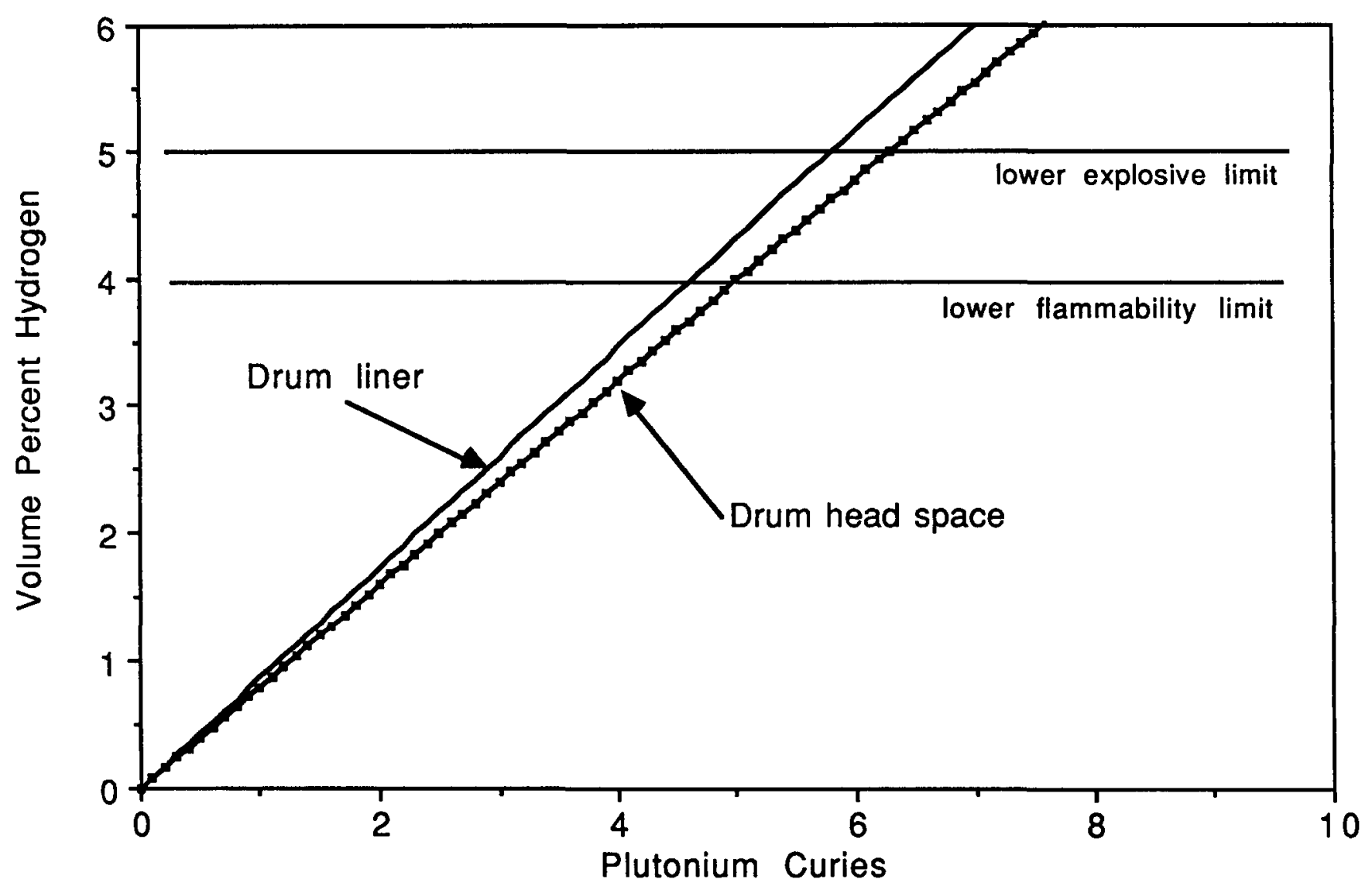

FIGURB 8. Model predictions of the steady state hydrogen gas concentration within the drum liner and head space for an unvented TRU waste drum containing polyethylene waste 


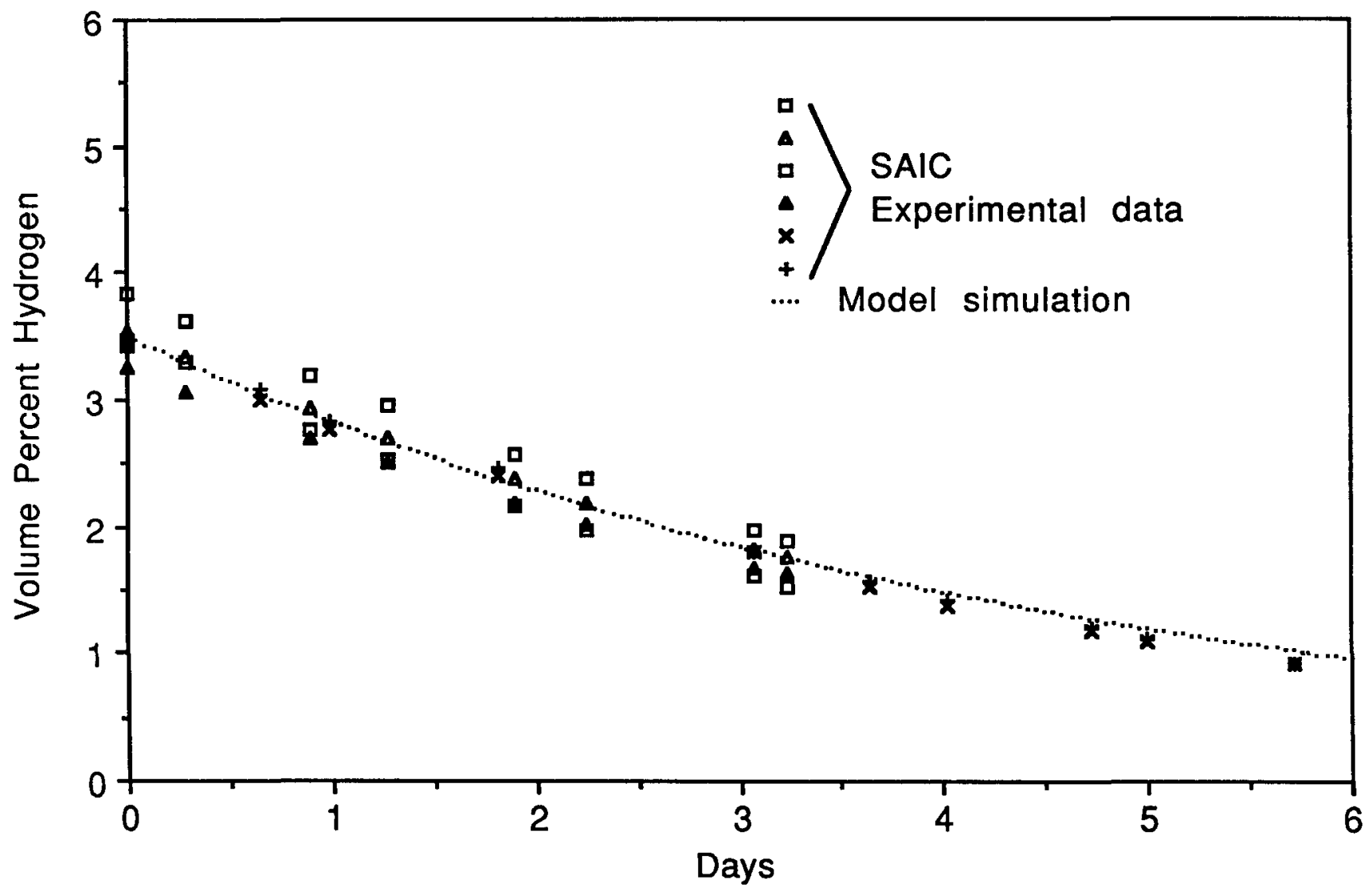

FIGURE 9. Model simulation of SAIC diffusion experiments using a $0.75^{\prime \prime}$ carbon composite filter vent without a cover 


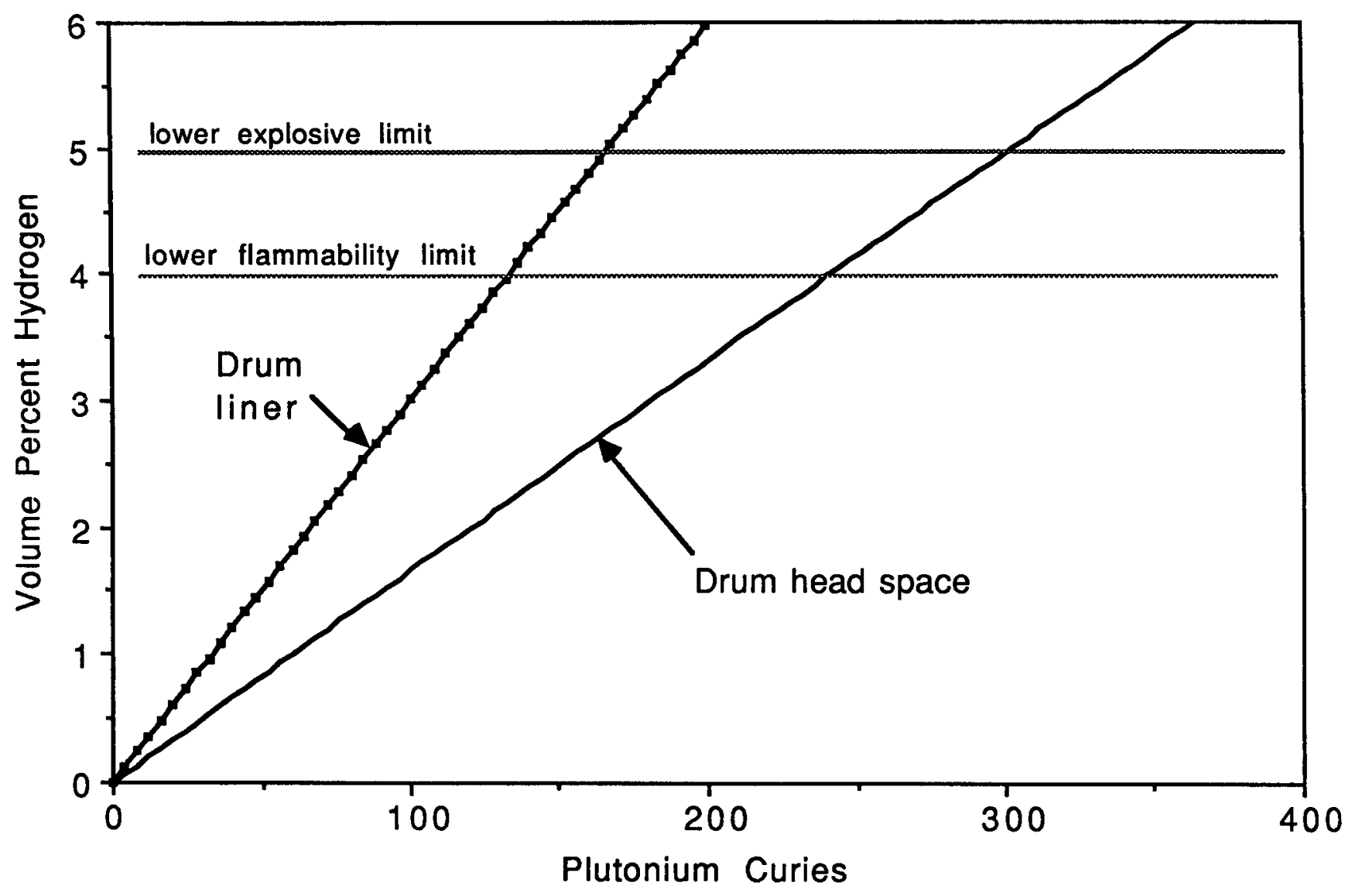

FIGURE 10. Model predictions of the steady state hydrogen gas concentration within the drum $l i n e r$ and head space for a TRU waste drum containing polyethylene waste that is vented with uncovered $0.75^{\prime \prime}$ filters 


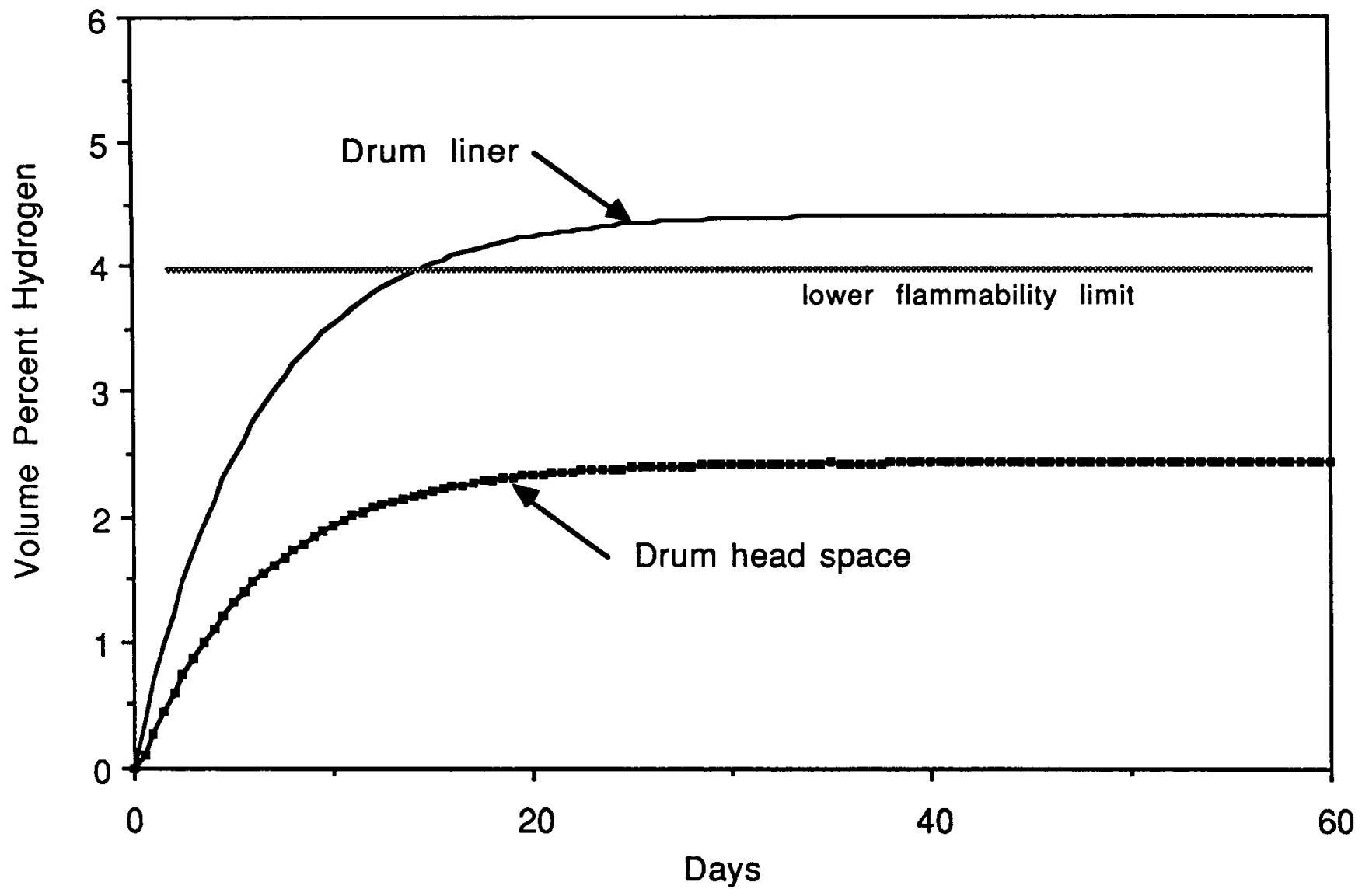

FIGURE 11. Transient hydrogen gas concentrations within the liner and drum head space for a TRU waste drum with $166 \mathrm{Ci}$ of plutonium on polyethylene waste that is vented with uncovered $0.75^{\prime \prime}$ filters 


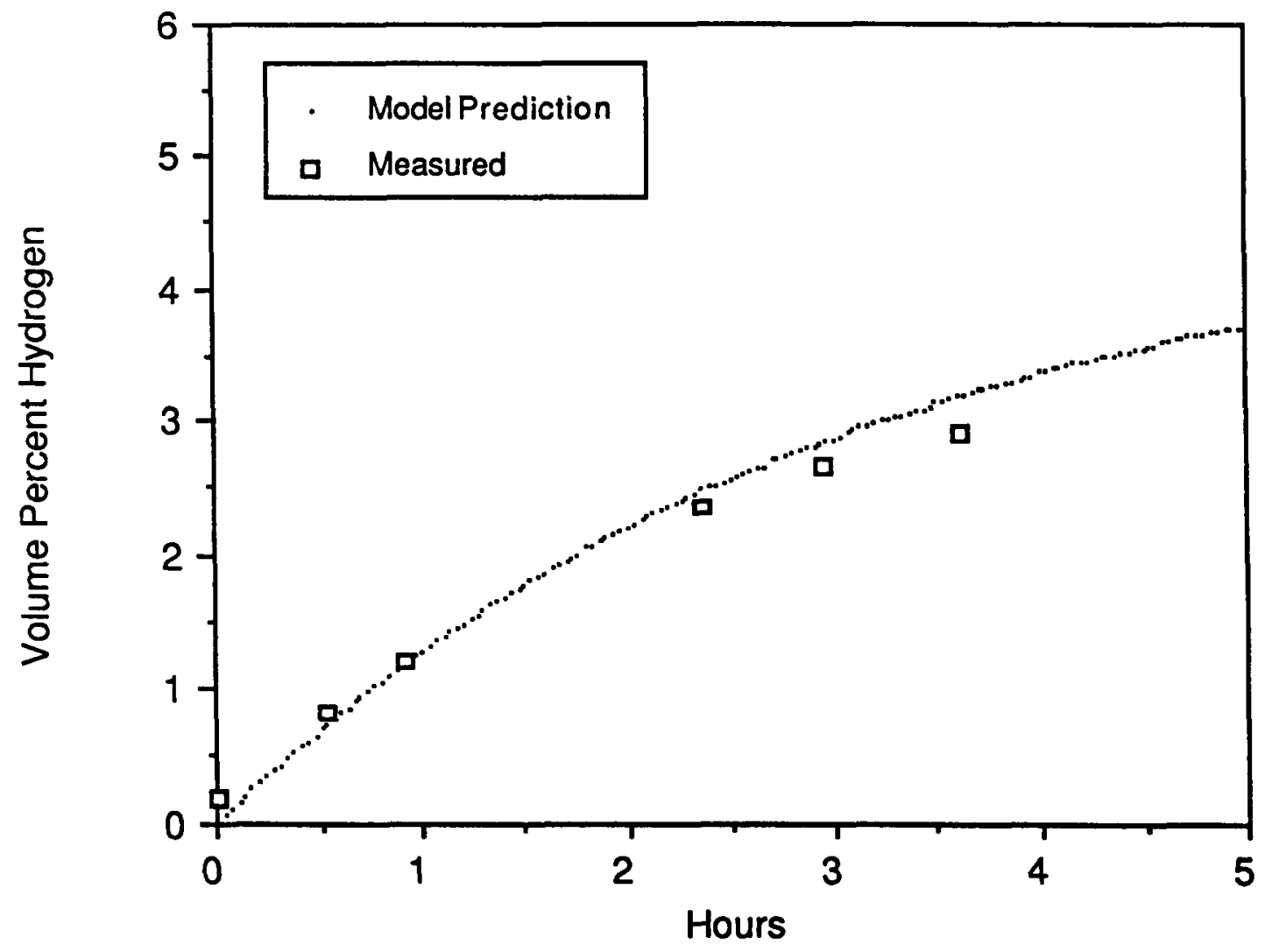

FIGURE 12. Model simulation of SRP diffusion experiments using a $0.75^{\prime \prime}$ carbon composite filter vent without a cover on a 4170 cc cylinder with hydrogen gas addition at a rate of $1.0 \mathrm{cc} / \mathrm{min}$ 


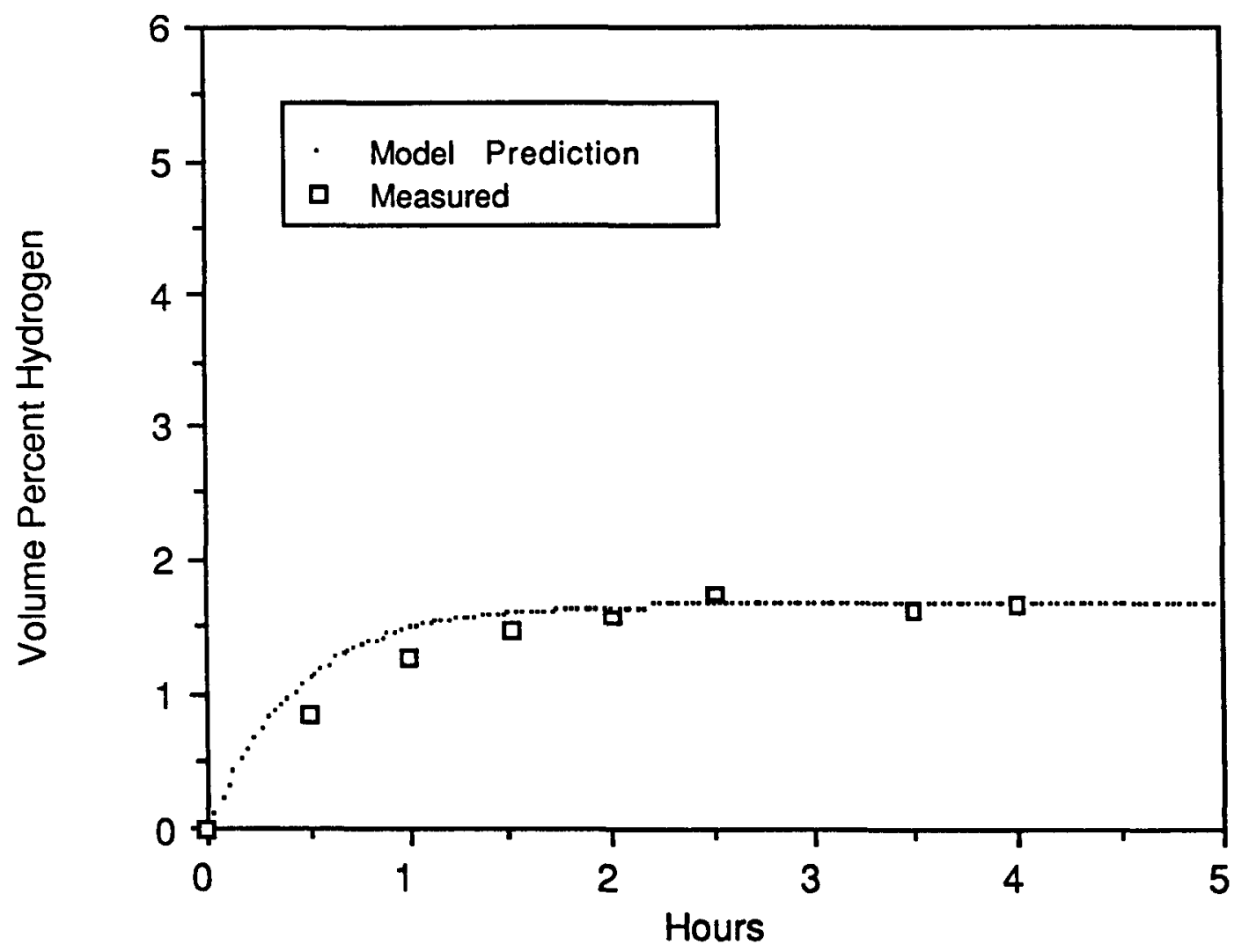

FIGURE 13. Model simulation of SRP diffusion experiments using a 2.0" carbon composite filter vent without a cover on a 4170 cc cylinder with hydrogen gas addition at a rate of $2.5 \mathrm{cc} / \mathrm{min}$ 


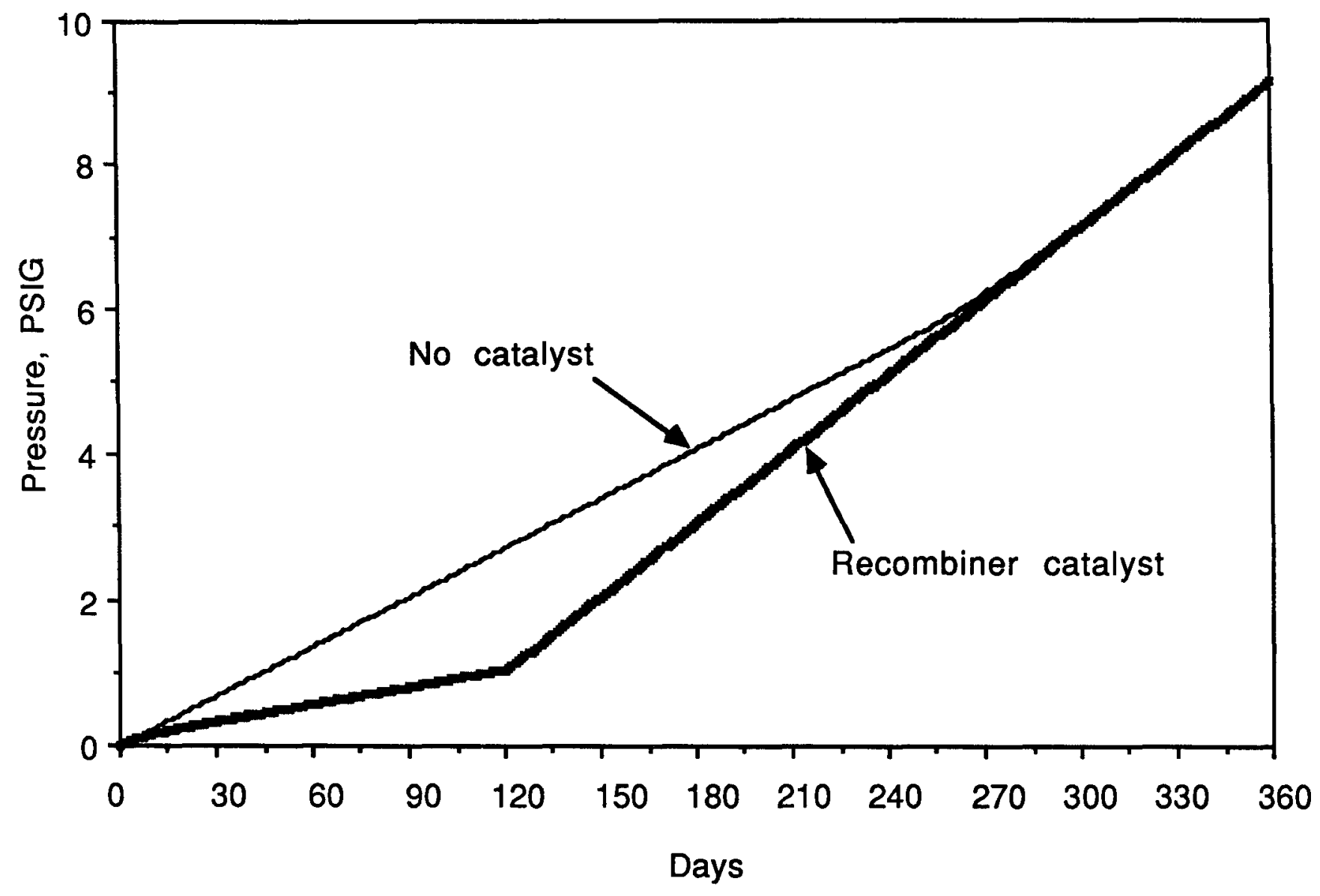

FIGURE 14. Model simulation of the pressure within the TRUPACT shipping container with and without a recombiner catalyst present 


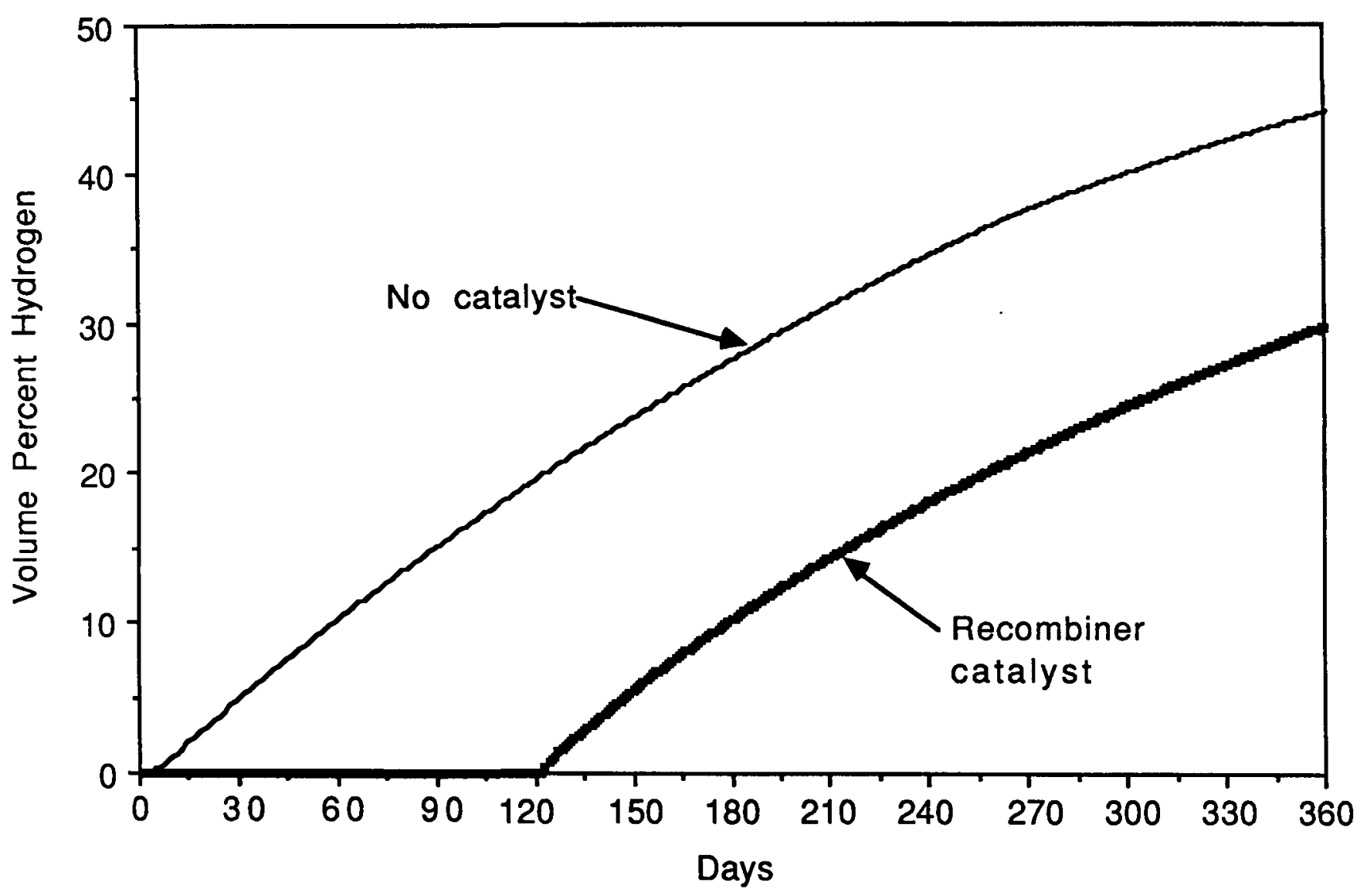

FIGURE 15. Model simulation of the hydrogen gas concentration within the TRUPACT shipping container with and without a recombiner catalyst present 


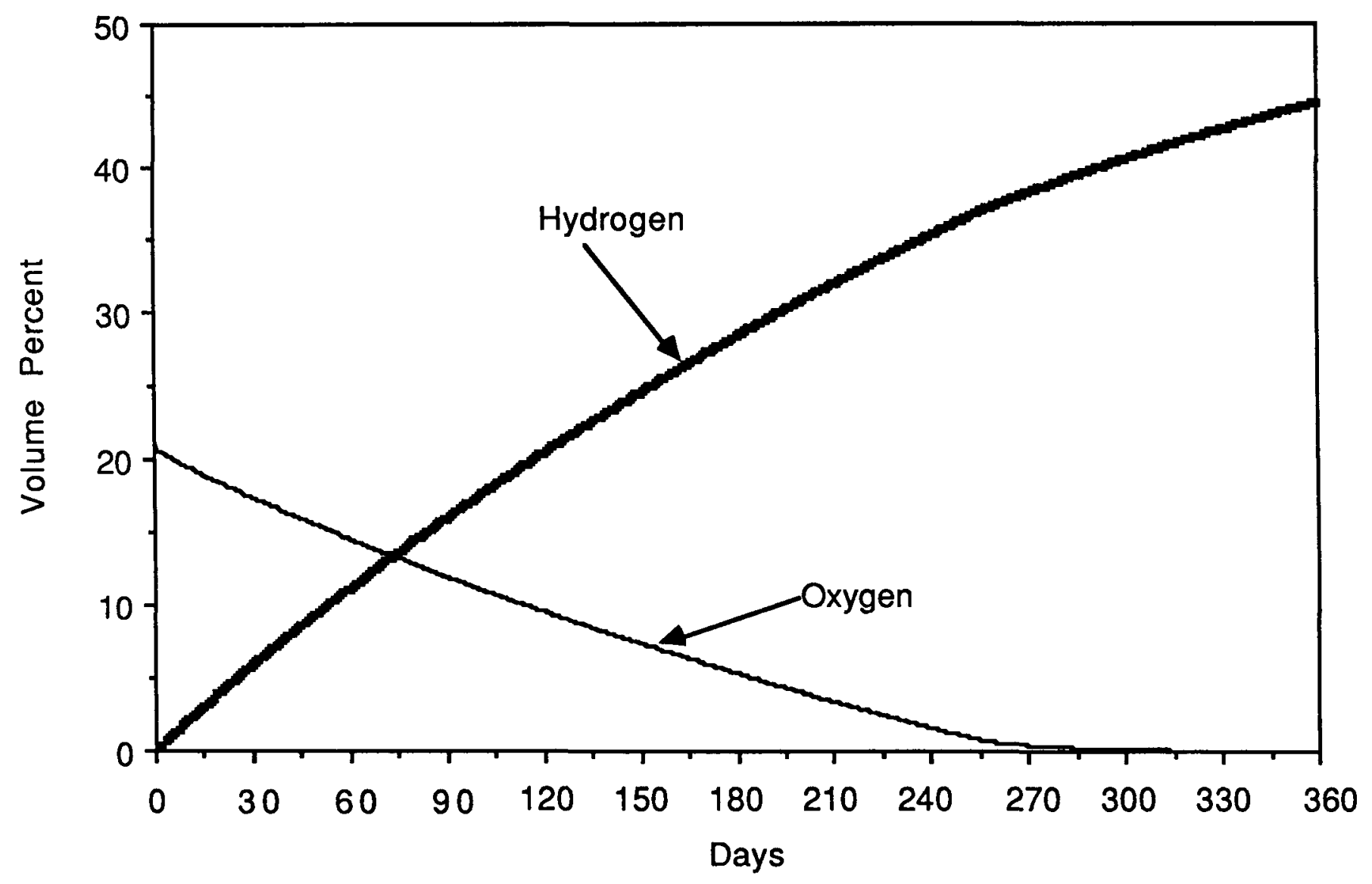

FIGURE 16. Model simulation of the hydrogen and oxygen gas concentrations within the drum head space for waste drums within the TRUPACT shipping container without the presence of recombiner catalyst 


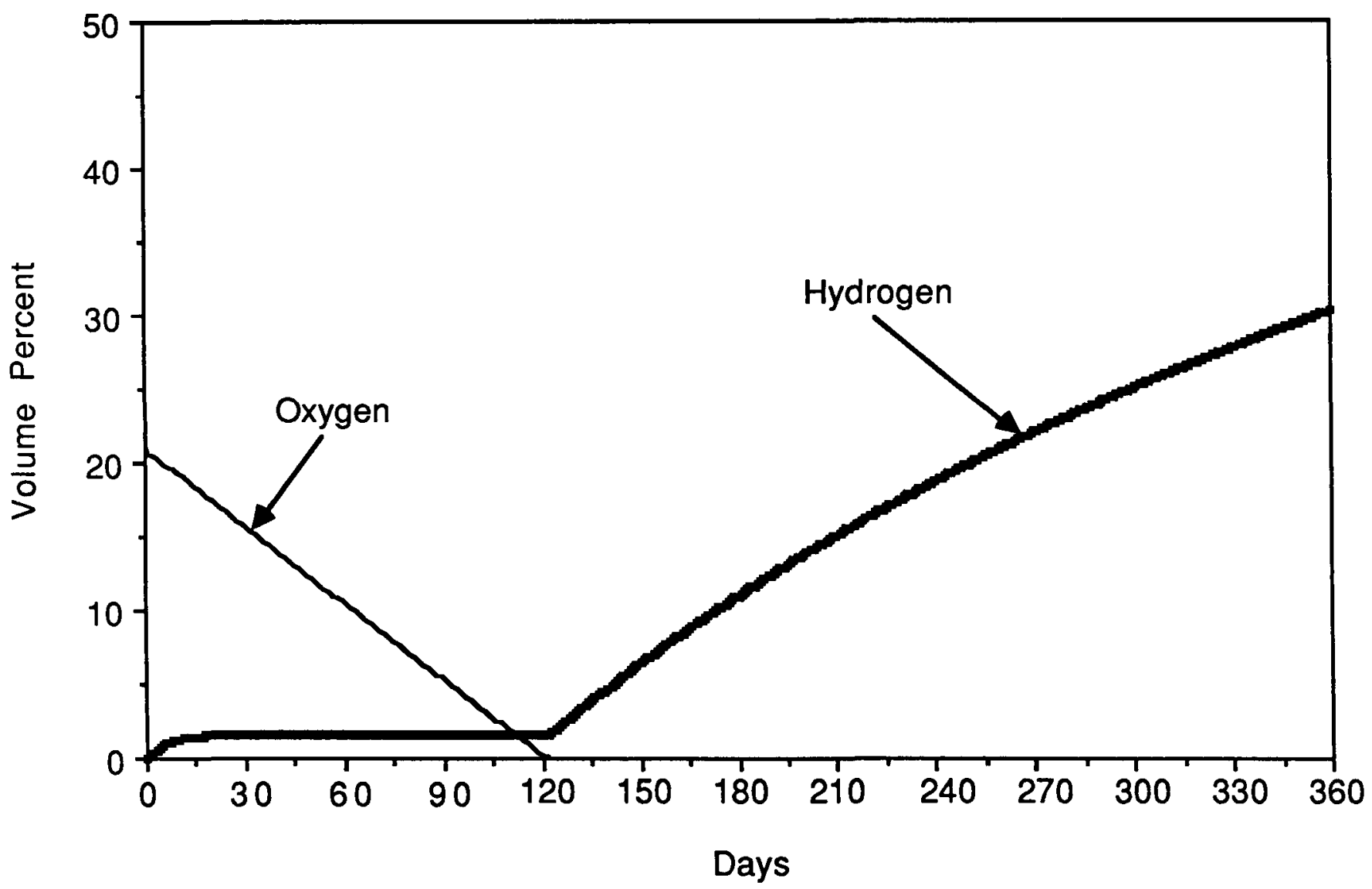

FIGURB 17. Model simulation of the hydrogen and oxygen gas concentrations within the drum head space for waste drums within the TRUPACT shipping container with recombiner catalyst present 


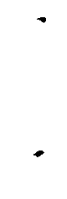




\section{NUMERICAL METHODS}

Equations (1), (2), and (3) presented in the Gas Generation Model and Gas Transport Model sections of the report are solved numerically for each gas present in the drum. A finite differencing scheme based on a Crank-Nicolson implicit method was employed in the numerical calculations (10). The method was found to be stable and accurate for this set of equations with time steps on the order of one hour. The accuracy of the calculations was verified by comparing model results to analytical solutions for certain simplified cases.

Assuming that the ideal gas law applies, the gas concentration can be related to the partial pressure as:

$$
C(i, k)=P(i, k) / R T
$$

where $R$ is the gas constant and $T$ is the absolute temperature. Combining Eq. (4) and Eq. (3) leads to a simplified expression for the molar gas flux as:

$$
J(i, k)=K(i, k) *[P(i, k)-P(i+l, k)] / X(i)
$$

where

$$
K(i, k)=D_{b}(i, k)+D_{0}(i, k) * Y(i)^{2} / R T
$$

and it is assumed that the transport path lengths $x_{b}(i)$ and $x_{0}(i)$ are equal to the material thickness $X(i)$.

Equation (2) may then be rewritten as:

$$
\begin{aligned}
w(i) \frac{d[P(i, k)]}{d t}= & G r(i, k)+u(i, k) *[P(i+1, k)-P(i, k)] \\
& -u(i-1, k) *[P(i, k)-P(i-1, k)]
\end{aligned}
$$

where $w(i)=V(i) / R T$ and $u(i, k)=A(i) * K(i, k) / X(i)$

It is then required to solve a system of coupled differential equations of the general form shown in Eq. (7) for each volume element $i$ and each gas species $k$. As a further simplification, it is assumed that the transport of each gas species occurs independently of the other gases present. Therefore, the system of equations for each gas can be solved independently. 
At time step $n$, a stable implicit numerical approximation to Eq. (7) can written as:

$$
\begin{aligned}
w(i) *[P(i, k, n+1) & -P(i, k, n)] / \Delta t= \\
G r(i, k) & +u(i, k) *[P(i+1, k, n+1)+P(i+1, k, n)] / 2 \\
& -u(i, k) *[P(i, k, n+1)+P(i, k, n)] / 2 \\
& -u(i-1, k) *[P(i, k, n+1)+P(i, k, n)] / 2 \\
& +u(i-1, k) *[P(i-1, k, n+1)+P(i-1, k, n)] / 2
\end{aligned}
$$

Multiplying through by $\Delta t$, letting $a(i, k)=u(i, k) \Delta t / 2$, and collecting terms yields:

$$
\begin{aligned}
& -a(i-1, k) * P(i-1, k, n+1)+[w(i)+a(i-1, k) \\
& +a(i, k)] * P(i, k, n+1)-a(i, k) * P(i+1, k, n+1)= \\
& \quad G r(i, k) * \Delta t+a(i-1, k) * P(i-1, k, n) \\
& +[w(i)-a(i-1, k)-a(i, k)] * P(i, k, n)+a(i, k) * P(i+1, k, n)
\end{aligned}
$$

Some additional simplification is possible by solving for the sum of the pressures at the two time steps

$$
s(i, k, n+1)=P(i, k, n+1)+P(i, k, n)
$$

Introducing Eq. (10) into Eq. (9) yields:

$$
\begin{aligned}
& -a(i-1, k) * S(i-1, k, n+1)+[w(i)+a(i-1, k) \\
& +a(i, k)] * S(i, k, n+1)-a(i, k) * S(i+1, k, n+1)= \\
& \quad G r(i, k) * \Delta t+2 w(i) * P(i, k, n)
\end{aligned}
$$

Equation (11) is the usual tridiagonal matrix form that arises from a Crank-Nicolson finite differencing scheme. The index $i$ varies over all volume elements and terms that evaluate to $i=0$ are not included in the solution. When $i=I$ for the final volume element, the pressures $P(I+1, k, n+1)$ and $P(I+1, k, n)$ are the known ambient values, $P(0, k)$, and the constant term

$$
-a(I, k) * S(I+1, k, n+1)=-2 * a(I, k) * P(0, k)
$$

must be shifted to the right hand side of Eq. (11). 
Equations (11) and (10) are solved over all of the volume elements for each gas species at each time step. Efficient numerical methods exist for the solution of tridiagonal systems (10) and the model can easily be extended to include additional volumes around the waste drum. For long term simulations, time steps of one hour were commonly used without difficulty. The implicit numerical approximation should be unconditionally stable.

The total pressure within the volumes is calculated as the sum of the individual partial pressures. When two or more volumes are connected by a filter vent, the pressure is equalized between the volumes and the gas partial pressures adjusted for the change in total pressure. While a slight pressure differential may occur in some cases with filters present, attempts to more exactly calculate the small volume pressures were too time consuming for practical model applications.

Equation (7) can be solved immediately for the steady state solution by equating the right hand side to zero. This gives a set of equations for each gas species that can be combined to show that :

$$
\operatorname{Ps}(i, k)=\operatorname{Ps}(i+1, k)+\sum_{m}^{i} \operatorname{Gr}(m, k) / u(i, k)
$$

where $P s(i, k)$ is the partial pressure of gas species $k$ in volume element $i$ at steady state. Equations (12) can be easily solved by starting with $i=I$ and $P s(I+l, k)=P s(0, k)$ and working backward to $\mathrm{i}=1$. 